\title{
ROLA MARKETINGU SPOŁECZNOŚCIOWEGO W ZARZADDZANIU RELACJAMI Z WIDZAMI SERIALI TELEWIZYJNYCH NA PRZYKŁADZIE PRODUKCJI ZAKOCHANI PO USZY
}

\author{
Abstract \\ THE ROLE OF SOCIAL MEDIA MARKETING IN TELEVISION VIEWER \\ RELATIONSHIP MANAGEMENT BASED ON THE TV PRODUCTION \\ ZAKOCHANI PO USZY
}

Social media marketing is becoming the main aspect of strategies implemented by traditional media workers. The aim of the study is an analysis of an impact this kind of internet marketing has on television viewer relationship management, in the form of case study. The author's intention was to do the qualitative research on the TV production Zakochani po uszy created by TVN, including its promotion through an official profile on the social networking site called Instagram in terms of building relationships with viewers along with holistic and deepened description of analysed phenomena. In the study, the author presents the results of the research based on non-participant observation of the official profile of Zakochani po uszy on Instagram, in-depth interview with a person responsible for public relations of the series, results of the survey along with data analysis, which contains viewership and statistics from analysed profile. These activities enabled solving the research problem phrased as a question: how is the strategy, which is to create strong relations with viewers, formulated and answering detailed research questions posed in the study.

Keywords: social media marketing, relationship management, Instagram, tv series, Zakochani po uszy

1 Artykuł powstał na podstawie pracy dyplomowej przygotowanej w Instytucie Kultury UJ w 2020 roku. 


\section{Wprowadzenie}

Konwergencja mediów oraz cyfryzacja spowodowały zmiany na rynku audiowizualnym w zakresie zarządzania organizacjami medialnymi, jak również wzmocniły potrzeby aktywnego nawiązywania relacji i komunikacji z odbiorcami. Według Bogusława Nierenberga (2011, s. 15) dzięki tym dwóm zjawiskom ludzie są świadkami rewolucji komunikacyjnej. Autor wyróżnił determinanty, jakie należy brać pod uwagę przy strategii organizacji medialnych, do których zalicza się zmianę struktury przemysłu medialnego, globalizację rynków medialnych, rewolucję informacyjną czy też rosnące oczekiwania klientów (Nierenberg, 2011, s. 15). Zgodnie z przewidywaniami badacza obecnie funkcjonowanie mediów oraz zarządzanie nimi (oprócz konwergencji i cyfryzacji) określają m.in. nowe media i społeczności wirtualne (Nierenberg, 2011, s. 16). Aby docierać do nowych grup odbiorców oraz identyfikować i spełniać ich potrzeby, media tradycyjne nie mogą lekceważyć wyżej wymienionych tendencji. Niniejszy tekst skupia się na nowych zjawiskach oraz specyfice telewizji w dobie konwergencji mediów.

Moim celem jest analiza wpływu marketingu społecznościowego na zarządzanie relacjami z widzami serialu telewizyjnego. Artykuł ten stanowi studium przypadku - badanie o charakterze jakościowym produkcji serialu telewizji TVN Zakochani po uszy (2019) pod kątem jego jednoczesnej promocji w mediach społecznościowych, zwłaszcza na Instagramie, w kontekście budowania relacji z odbiorcami. Zgodnie z założeniem metody studium przypadku intencją autorki było stworzenie opisu o charakterze holistycznym i pogłębionym, motywowane pragnieniem zrozumienia analizowanych zjawisk. Problem badawczy został sformułowany w postaci pytania: w jaki sposób tworzy się strategię, która ma kreować silne więzi z widzami serialu? Przedmiotem analizy była przede wszystkim strategia realizowana przez stację telewizyjną TVN, która została omówiona podczas wywiadu swobodnego pogłębionego z osobą odpowiedzialną za public relations stacji wraz $\mathrm{z}$ danymi statystycznymi udostępnionymi przez organizację, a także medium społecznościowe, bezpośrednio powiązane z produkcją serialu, czyli Instagram.

$\mathrm{W}$ pracy postawione zostały również szczegółowe pytania badawcze: jaka współzależność występuje pomiędzy oglądalnością serialu a aktywnością jego obserwatorów w social mediach? Jakie rodzaje postów wywołują najwyższe aktywności użytkowników? Jaka współzależność istnieje pomiędzy częstotliwością dodawania postów a zaangażowaniem użytkowników Instagrama? Jak aktywność użytkowników mediów społecznościowych wpływa na produkcję serialu i czy w ogóle ma ona jakiś bezpośredni wpływ?

Organizacja, która została wybrana przeze mnie jako przedmiot badań w tym studium przypadku, to komercyjna telewizja TVN. Należy ona do medialnego koncernu Discovery, stowarzyszenia „czołowych europejskich grup mediowych” European Media Alliance, a ponadto jest przede wszystkim jednym z dominujących polskich nadawców telewizyjnych (O nas, 2020). Telewizja ta, po uzyskaniu 
koncesji w 1996 roku, wyemitowała swój pierwszy program w 1997 roku. Od maja 2018 roku funkcję prezesa zarządu pełni w niej Piotr Korycki (Zespół zarządzający TVN..., 2020). Stacja posiada swoje ośrodki regionalne w wielu miastach na terenie Polski, m.in. w Katowicach, Gdańsku, Wrocławiu, Poznaniu, Łodzi czy Krakowie (Programy..., 2020). Aby przeprowadzić badania, skontaktowałam się z pracownikami oddziału w tym ostatnim mieście. To właśnie w krakowskim ośrodku TVN produkowany jest serial Zakochani po uszy, który swoją premierę miał w styczniu 2019 roku, i to właśnie tam tworzona jest strategia zarządzania mediami społecznościowymi bezpośrednio związanymi z tym serialem.

Założenia przyjęte do zrealizowania pokrywają się z paradygmatem interpretatywnym, który wyróżniony został jako jeden z czterech podstawowych paradygmatów w klasyfikacji Garetha Morgana oraz Gibsona Burrella (1979, s. 28). W badaniach postrzegałam bowiem rzeczywistość w sposób subiektywny, analizując konkretny przypadek w danym miejscu i czasie, ponadto było to związane $\mathrm{z}$ socjologią regulacji, czyli opisywaniem rzeczywistości bez propozycji dokonywania zmian.

Do napisania pracy oraz przeprowadzenia powyższych badań wykorzystane zostały metody badawcze zarówno z nurtu jakościowego, jak i ilościowego. Były to: obserwacja nieuczestnicząca, wywiad swobodny pogłębiony, analiza danych zastanych, a także kwestionariusz ankiety. Obserwacja nieuczestnicząca posłużyła jako jedna $z$ technik stanowiących wstęp do dalszych badań. Poprzez regularne tworzenie notatek oraz początkowe przyjęcie roli badacza nieuczestniczącego, zachowującego neutralność i obiektywizm, już po krótkim czasie uzyskałam pierwsze wyniki pracy, które wykorzystałam jako uzupełnienie innych technik badawczych. Wywiad swobodny, przeprowadzony z pracownikiem organizacji, pozwolił na pogłębiony wgląd w badaną problematykę. Analiza danych zastanych udostępnionych przez organizację dała możliwość opisania oraz wyjaśnienia długookresowych trendów związanych z produkcją serialu, które umożliwiły odpowiedzenie na postawione w pracy pytania badawcze. Kwestionariusz ankiety umożliwił zbadanie grupy respondentów, potencjalnych widzów serialu Zakochani po uszy, którzy przez udzielenie odpowiedzi na pytania dostarczyli informacji o charakterze uzupełniającym. Zastosowanie triangulacji metod badawczych, polegającej na zestawieniu danych pozyskanych $\mathrm{z}$ wywiadu swobodnego pogłębionego oraz kwestionariusza ankiety, umożliwiło przeprowadzenie wielowymiarowej analizy.

Praca sytuuje się w dyscyplinie nauki o zarządzaniu. Posłużyłam się w niej pojęciami takimi jak: strategia, organizacja, otoczenie organizacji, misja, wizja czy podejmowanie decyzji. Wnioski z badań zostały skonfrontowane z literaturą z zakresu nauk o zarządzaniu, tj. m.in. z książką pod redakcją Andrzeja K. Koźmińskiego oraz Włodzimierza Piotrowskiego pt. Zarządzanie. Teoria i praktyka. Ponadto praca dotyczy bezpośrednio rynku medialnego, a konkretnie telewizyjnego oraz nowych mediów. Aby zgłębić temat, operowałam pojęciami takimi jak: zarządzanie mediami, konwergencja mediów, promocja czy marketing społecznościowy. 
Całość jest złożona z czterech rozdziałów. W rozdziale pierwszym przedstawione zostały definicje wyżej wymienionych pojęć z zakresu nauk o zarządzaniu oraz tych powiązanych $\mathrm{z}$ rynkiem medialnym, jak również przegląd literatury przedmiotu ze wskazaniem publikacji poruszających badaną problematykę. Rozdział drugi omawia metodologię pracy $\mathrm{z}$ wyszczególnieniem paradygmatu oraz metod badawczych wykorzystanych podczas badań. Prezentujący wyniki badań rozdział trzeci został podzielony na cztery podrozdziały, opisujące chronologicznie etapy prowadzonych działań wraz $\mathrm{z}$ interpretacją uzyskanych rezultatów. W rozdziale czwartym przedstawione i omówione wyniki badań zestawiono $\mathrm{z}$ dorobkiem literatury oraz rozważono pod kątem ich naukowego znaczenia. Całość podsumowuje zakończenie, odwołujące się do zakładanego celu i pytań badawczych, w którym zebrano wnioski zamykające.

\section{Przegląd literatury przedmiotu}

Bogusław Nierenberg (2011, s. 79) definiuje zarządzanie mediami (w ujęciu systemowym) jako „zespół wzajemnie powiązanych procesów i czynności obejmujących: planowanie, organizowanie, przewodzenie i motywowanie oraz kontrolowanie, odnoszących się do wszystkich przejawów i poziomów systemu medialnego". Zarządzanie relacjami według Bartosza i Przemysława Deszczyńskich jest:

(...) strategią (...) polegającą na budowaniu lojalności klientów wobec przedsiębiorstwa/ marki, poprzez rozwijanie długoterminowych związków, przynoszących korzyści obu stronom, z zastosowaniem najnowszych osiągnięć technologii przetwarzania informacji (Deszczyński, Deszczyński, 2004, s. 173).

Za Rickym W. Griffinem (2002, s. 35) należy przyjąć, iż organizacja to „grupa ludzi, którzy współpracują ze sobą w sposób uporządkowany i skoordynowany, aby osiągnąć pewien zestaw celów". Otoczenie organizacji, w ujęciu Andrzeja K. Koźmińskiego (2006, s. 33), jest „tym, co znajduje się na zewnątrz niej, poza jej granicami i oddziałuje na nią". Pojęcie strategii organizacji Krzysztof Obłój oraz Maciej Trybuchowski (2006, s. 127) rozumieją jako „przyjętą przez jej kierownictwo spójną koncepcję działania, której wdrożenie ma zapewnić osiągnięcie fundamentalnych celów długookresowych w ramach wybranej domeny działania”. Przy tworzeniu strategii należy także nakreślić misję organizacji, którą wyżej wymienieni autorzy uznają za „fundamentalny (często zresztą nieosiągalny), a równocześnie unikatowy stan przyszły, do którego organizacja zmierza. Misja jest ogólnym stwierdzeniem najbardziej podstawowych intencji” (Obłój, Trybuchowski, 2006, s. 166). Uzupełnia ją wizja zdefiniowana przez Monikę Kosterę, Stanisława Kownackiego i Adriana Szumskiego (2006, s. 353) jako „określenie stanu organizacji, jaki ma być osiągnięty przez nią w przyszłości. (...) różni się od misji sposobem określenia organizacji”. Powyższe postępowanie wiąże się z podejmowaniem decyzji, czego 
- odwołując się do stwierdzenia Barbary Czarniawskiej (1980, s. 5-12) - można się nauczyć, podejmując decyzje. Maciej J. Ramus oraz Piotr Szczepanowski (2006, s. 90-91) podkreślają, że z procesem decyzyjnym mamy do czynienia w momencie, w którym pewien stan zastany nie jest satysfakcjonujący, a ponadto utrzymanie go pociąga za sobą ryzyko negatywnych skutków. Co za tym idzie, należy poczynić odpowiednie kroki, aby stan zastany przeistoczyć w stan pożądany.

Pojęcie konwergencji w rozumieniu Henry'ego Jenkinsa (2007, s. 9) to przepływ treści między różnymi przemysłami oraz platformami w mediach. Autor zauważa, że wiąże się on ze zmianą kulturową, która polega na zachęcaniu odbiorców, aby wyszukiwali informacje, a także łączyli treści, które można odnaleźć w wielu środkach przekazu. Konwergencja w definicji Jenkinsa (2001) jest toczącym się procesem. Ze względu na szeroki zakres informacji, z którymi użytkownicy mediów stykają się każdego dnia - istotną składową działań medialnych jest promocja. Za Anną Jupowicz-Ginalską należy przyjąć, iż jest to:

(...) całokształt działań marketingowych, prowadzonych przez środki masowego przekazu w celu zaspokojenia potrzeb odbiorców, którymi są inne media, konsumenci i pozostałe grupy interesu. Media stają się więc zarówno nadawcami, pośrednikami, jak i odbiorcami przekazów marketingowych, a jednocześnie ich nośnikami, zwielokratniającymi i rozpowszechniającymi je na pożądaną przez nadawców/wydawców skalę (Jupowicz-Ginalska, 2010, s. 23).

Anna Drab-Kurowska (2012, s. 179) rozumie pojęcie marketingu społecznościowego jako „dziedzinę marketingu internetowego polegającą na pośredniej promocji poprzez komunikację z potencjalnymi klientami przy wykorzystaniu serwisów społecznościowych lub blogów poprzez umieszczanie lub wymianę artykułów, filmików czy obrazów".

Tematyka mediów społecznościowych staje się w ostatnich latach coraz bardziej powszechna, a badania nad nimi, czy też analizy ich funkcjonowania, coraz częściej pojawiają się w wielu publikacjach naukowych. Pomimo to, dokonując przeglądu literatury zarówno polskiej, jak i anglojęzycznej, zdiagnozowałam lukę dotyczącą problematyki współpracy mediów tradycyjnych z mediami społecznościowymi przy użyciu marketingu społecznościowego. Jest to temat relatywnie nowy, a zatem nie ma jeszcze zbyt wielu publikacji w tym zakresie. Ponadto podobne badania, dotyczące analizy Instagrama pod kątem zarządzania relacjami z widzami serialu telewizyjnego w Polsce - nie zostały jeszcze przeprowadzone. Wobec powyższego moje badania stanowiły próbę wypełnienia wskazanej luki poznawczej.

Wskazana problematyka podejmowana była już przez autorów wielu publikacji. Przeprowadzali oni także badania w obszarze social mediów oraz telewizji. Jednakże najczęściej podchodzili do tematu $z$ innej strony, np. kładąc nacisk na rolę autopromocji. Na temat współpracy mediów społecznościowych z mediami tradycyjnymi pisał już m.in. Przemysław Szews (2014, s. 57-71). Opisał on konwergencję mediów, przeanalizował wykorzystanie Internetu do promocji i zwiększania zasięgów mediów tradycyjnych. Autor posługiwał się przykładami zarówno z prasy, 
radia, jak i telewizji. Pisząc o tym ostatnim, wprowadził także pojęcie social TV, co rozumie jako określenie metod, które wspomagają komunikowanie się przy użyciu social mediów podczas oglądania telewizji. Wiąże się to z obserwacją zachowań widzów oraz badaniem ich reakcji, które wyrażają w serwisach (Szews, 2014, s. 6768). W swojej pracy nie podjął natomiast problematyki wykorzystania Instagrama. Również Ewa Gębicka (2017, s. 14-15) poruszyła szeroko problematykę marketingu społecznościowego. Wspomniała o roli prosumenta, czyli konsumenta, który przyczynia się do sukcesu lub porażki danej marki albo programu na rynku filmowym czy telewizyjnym (Gębicka, 2017, s. 15-16). Przeanalizowała różne przykłady mediów społecznościowych wykorzystywane do promocji i wspomniała konkretne przypadki, w których twórcy filmowi lub telewizyjni łączą się ze swoimi odbiorcami właśnie dzięki social mediom (Gębicka, 2017, s. 16-22). Autorka przedstawiła też działania społeczności wielbicieli różnych seriali oraz filmów, które dzięki swojej aktywności rozpowszechniają konkretne tytuły (Gębicka, 2017, s. 23-24). Jednakże pomimo dość szczegółowego zgłębienia wielu form promocji przy użyciu marketingu społecznościowego - w publikacji tej, podobnie jak w poprzedniej - nie pojawiła się analiza Instagrama.

O multiplatformowości w swoim artykule Multiplatformowa promocja treści. Prasa, radio i telewizja na sfragmentaryzowanym rynku mediów pisała Weronika Świerczyńska-Głownia (2019, s. 50-52). Jest to jedna z najbardziej aktualnych publikacji poruszających problematykę współpracy nadawców telewizyjnych z mediami społecznościowymi. Autorka poddała analizie przykłady działań promocyjnych w sieci, uwzględniając nawet typy postów, które według statystyk osiągają największe zasięgi w social mediach, oraz przykłady materiałów, które zainteresują potencjalnych widzów i pomogą w zarządzaniu relacjami z nimi. Marzena Barańska w artykule Rola autopromocji w zarzadzaniu oferta telewizyjna (2017, s. 780-784) także podkreśliła istotność kształtowania relacji z widzem oraz poruszyła problematykę autopromocji jako nieodłącznej części zarządzania mediami. W jej pracy pojawiło się pojęcie multiscreeningu, które zostało również wykorzystane w moich badaniach (Barańska, 2017, s. 786). W jej tekście nie było jednak analizy zarządzania relacjami przez wykorzystanie mediów społecznościowych, co analizuję w swoim artykule.

$\mathrm{Na}$ temat portalu Instagram $\mathrm{w}$ kontekście działań promocyjnych przedsiębiorstw pisała Patrycja Czarnota (2017, s. 134-138). W swoim artykule wytłumaczyła, czym jest ten portal społecznościowy, opisała możliwości, jakie mają zalogowani do niego użytkownicy, oraz zaprezentowała przykłady kampanii, które zakładały przyciągnięcie nowych użytkowników do konkretnych marek. Oprócz tego o Instagramie można przeczytać również w artykule Anny Modzelewskiej-Stalmach (2018, s. 27-30). Autorka także zdefiniowała w nim, czym jest ten serwis społecznościowy, jaka jest jego specyfika oraz jakie szanse daje on korzystającym z niego osobom. Jednakże analizowała ona Instagram z perspektywy kultury narcyzmu, a nie bezpośrednio promocji i marketingu (Modzelewska-Stalmach, 
2018, s. 30-32). Tematyka wyżej wymienionego portalu społecznościowego została również poruszona w wielu publikacjach anglojęzycznych. Yuheng Hu, Lydia Manikonda i Subbarao Kambhampati (2014, s. 595) zauważyli, iż użytkownicy Instagrama najczęściej udostępniają zdjęcia, które da się podzielić na osiem kategorii: przyjaciele, jedzenie, gadżety, zdjęcia z napisami, zwierzęta, aktywność, selfie oraz moda. Ponadto Saeideh Bakhshi, David A. Shamma oraz Eric Gilbert (2014, s. 971) przeprowadzili badania, z których wynika, iż zdjęcia prezentujące twarze osiągają statystycznie większą liczbę „polubień” oraz komentarzy (z wyszczególnieniem, że ich liczba, płeć ani wiek nie mają wpływu na zaangażowanie odbiorców).

Ważny w kontekście niniejszej pracy wydaje się także artykuł Efektywna promocja własna jako źródło wizerunkowego sukcesu organizacji medialnej - na przykładzie TVN S.A. Anny Jupowicz-Ginalskiej (2013, s. 390-401), która przeanalizowała działania promocyjne (i nie tylko) wybranej przeze mnie organizacji, przyczyniające się do jej sukcesu.

Warto zaznaczyć, że publikacje krajowe poruszają tematykę social media marketingu, przybliżając samo zjawisko oraz jego zastosowanie. Wyszczególniają także korzyści, jakie mogą z niego płynąć. O marketingu społecznościowym i jego roli napisała m.in. Anna Drab-Kurowska w artykule Social media marketing $w$ marketingu XXI wieku (2012, s. 179-185), a także Szymon Kępczyński w swojej pracy Media społecznościowe w marketingu (2017, s. 68-72).

\section{Metodologia pracy}

Przeprowadzenie badań, umożliwiających realizację podstawowego celu pracy, jakim jest analiza wpływu marketingu społecznościowego na zarządzanie relacjami z widzami serialu telewizyjnego, zakładało posłużenie się metodami badawczymi z nurtu jakościowego, jak również ilościowego, co pozwoliło na spełnienie metodologicznego wymogu triangulacji, który Monika Kostera oraz Paweł Krzyworzeka (2012, s. 172) uznają za „dążenie do zebrania materiału przy użyciu różnych metod z wielu źródeł". W kontekście zdefiniowanego problemu badawczego oraz przyjętego paradygmatu interpretatywnego, który w rozumieniu Moniki Kostery (2003, s. 192-193) „opiera się na założeniu, że prawda o otaczającym nas świecie zmienia się w zależności od tego, kto ją widzi i przedstawia”, fundamentalne znaczenie miała metodologia jakościowa. Rezultatem jej przyjęcia było zapoznanie się z działaniami podejmowanymi przez stację telewizyjną TVN w mediach społecznościowych w celu kreowania więzi z widzami serialu Zakochani po uszy oraz ich rezultatami.

Wobec powyższego badania zostały rozpoczęte od wykorzystania metody badawczej, jaką jest obserwacja nieuczestnicząca, która według Moniki Kostery oraz Pawła Krzyworzeki (2012, s. 173) wiąże się ze świadomą próbą doświadczania społecznej rzeczywistości, jednak z wyłączeniem przypisanych jej znaczeń. Zgodnie z ujęciem wyżej wymienionych badaczy ten rodzaj obserwacji umożliwia odkrycie 
nowych aspektów rzeczywistości, z którą osoba badająca miała już wcześniej styczność, a nawet mogła dobrze ją znać (Kostera, Krzyworzeka, 2012, s. 173). Ponadto posłużenie się obserwacją nieuczestniczącą jako narzędziem jest przydatne w kontekście etnografii wirtualnej, o czym napisali Piotr Cichocki, Tomasz Jędrkiewicz i Robert Zydel (2012, s. 204-209), wyszczególniając, iż warto wykorzystać ją np. do planowania strategicznego, komunikacji marketingowej czy też ewaluacji wielu działań marketingowych, bazując na spontanicznych reakcjach konsumentów.

Analiza profilu instagramowego serialu Zakochani po uszy pod kątem aktywności użytkowników przed, w trakcie, a także po emisji odcinków w telewizji, liczby publikowanych postów, z uwzględnieniem ich rodzajów oraz liczby obserwujących, pozwoliła na wyostrzenie percepcji i była podstawą do kolejnego etapu badania. Wykorzystanie wywiadu swobodnego pogłębionego, który Svetlana Gudkova (2012, s. 115) definiuje jako „rodzaj wywiadu niestandaryzowanego i nieustrukturyzowanego, podczas którego badacz swobodnie kształtuje rozmowę”, było zasadniczym źródłem wiedzy dla projektu badawczego. Rozmowa została przeprowadzona $\mathrm{z}$ osobą odpowiedzialną za public relations badanego formatu, która na co dzień zajmuje się tworzeniem strategii w mediach oraz prowadzeniem profili serialu Zakochani po uszy w serwisach społecznościowych. Wywiad przyjął formę zdalną.

Równolegle do wyżej wymienionej metody badawczej wykorzystana została także analiza danych zastanych. Earl Babbie (2003, s. 353) podkreśla, że powinien to być nieodłączny element badania, ponieważ istniejące dane mogą ujawnić kontekst historyczny lub pojęciowy określonego tematu. Ponadto za Zofią Bednarowską (2015, s. 19) należy przyjąć, iż powyższa metoda „może wzbogacić dotychczasowe mechanizmy wnioskowania w danym temacie". Dominujące znaczenie dla badania miały statystyki pochodzące $\mathrm{z}$ konta Zakochanych po uszy w serwisie Instagram, na które składają się zasięgi, wyświetlenia, interakcje czy grupa odbiorców wraz z godzinami ich największej aktywności, jak również statystyki dotyczące oglądalności serialu. Po rzetelnym zebraniu informacji zostały dokonane synteza oraz interpretacja zgromadzonego materiału w celu odpowiedzi na pytania badawcze postawione w pracy.

Metodologia ilościowa miała dla projektu badawczego znaczenie uzupełniające. Posłużenie się kwestionariuszem ankiety, zdefiniowanym przez Earla Babbiego (2003, s. 270) jako narzędzie zaprojektowane celowo, aby zbierać informacje przydatne do analiz, zakładało zapoznanie się z opiniami potencjalnych widzów serialu Zakochani po uszy na temat produkcji, które miały potwierdzić lub zakwestionować założenia przyjęte po przeprowadzeniu wywiadu swobodnego pogłębionego i analizie danych zastanych. Próba badawcza została dobrana w sposób umożliwiający zgłębienie opinii internautów. Badania nie miały jednak charakteru reprezentatywnego. Kwestionariusz ankiety składał się $\mathrm{z}$ dziewięciu pytań zamkniętych (w tym pięć z nich uwzględniało możliwość wpisania dodatkowego wariantu odpowiedzi) oraz dwóch pytań otwartych (z których jedno było pytaniem o wiek respondenta), 
jednakże odpowiedź na wszystkie była wymagana jedynie od osób, które zadeklarowały, iż znają uwzględniony w badaniu serial, a także odwiedzają profil Zakochanych po uszy na Instagramie.

\section{Prezentacja wyników badań}

$\mathrm{W}$ tej części pracy opisano wyniki badań, przeprowadzonych z wykorzystaniem wyżej wymienionych metod badawczych, oraz podano ich interpretację. Poszczególne działania zostały zaprezentowane chronologicznie, co pozwoliło na przedstawienie wyników w sposób logiczny i spójny. Wobec powyższego opis rozpoczyna się od analizy rezultatów obserwacji nieuczestniczącej, następnie omówione zostały wyniki wywiadu swobodnego pogłębionego, w dalszej kolejności - analiza danych zastanych, a na koniec analiza wyników kwestionariusza ankiety.

\subsection{Analiza rezultatów obserwacji nieuczestniczącej - pierwszy etap badań}

Obserwację nieuczestniczącą konta instagramowego Zakochanych po uszy rozpoczęłam w połowie października 2019 roku i regularnie prowadziłam do początku drugiej połowy grudnia 2019 roku. W tym czasie tworzyłam notatki, na bieżąco oglądałam serial i odwiedzałam jego oficjalny profil na Instagramie. Później nastąpiły trzy tygodnie przerwy, podczas których nie prowadziłam codziennych obserwacji. Emisja drugiego sezonu serialu zakończyła się, a premiera sezonu trzeciego przewidziana była na 13 stycznia 2020 roku. W związku z powyższym prawie tydzień wcześniej, 7 stycznia, powróciłam do regularnych obserwacji profilu, aby przeanalizować także to, co działo się z nim, kiedy serial nie był emitowany. Moje regularne obserwacje trwały do 11 marca 2020 roku. Prowadziłam je przez pięć dni w tygodniu - od poniedziałku do piątku. Serial jest bowiem emitowany w telewizji od poniedziałku do czwartku, a co za tym idzie - w poniedziałki przed emisją odcinka analizowałam, co zmieniło się na profilu w ciągu weekendu, a w piątki sprawdzałam, jak wyglądała aktywność użytkowników na koncie dzień po emisji ostatniego odcinka w tygodniu.

Aktywności, które podejmowałam podczas obserwacji, to: wejście na profil $\mathrm{Za}$ kochanych po uszy na około 20 minut przed emisją odcinka w telewizji, która rozpoczynała się o 19.30, analiza tego, co działo się na profilu w ciągu dnia, następnie obserwacja na bieżąco w trakcie emisji, uwzględniająca, jak zmienia się aktywność podczas reklam (22-minutowy odcinek zawsze był przerywany jednym blokiem reklamowym, mniej więcej po 17 minutach od rozpoczęcia), oraz pozostanie na profilu jeszcze przez około 15 minut po zakończeniu odcinka. W czasie obserwacji zwracałam uwagę na aspekty, których na co dzień nie dostrzegałam. Sprawdzałam, jak zmienia się liczba obserwujących każdego dnia, jakie rodzaje postów są zamieszczane na profilu, ile postów dziennie jest publikowanych, co pojawia się 
$\mathrm{w}$ instastories oraz w jaki sposób pora dnia wpływa na ilość i rodzaj udostępnianych treści czy zaangażowanie pod poszczególnymi postami. Analizowałam też aktywność użytkowników w trakcie trwania odcinków - czy posty, które są wtedy dodawane, są również na bieżąco komentowane i lajkowane oraz jak fakt, iż w telewizji nadawane są reklamy, oddziałuje na aktywność widzów na Instagramie. Z prowadzonych przeze mnie obserwacji powstało 16 stron notatek.

Pierwszym z rezultatów obserwacji było wyszczególnienie typów postów, które regularnie powtarzały się na profilu Zakochanych po uszy. Były to: cytaty, czyli ujęcia $\mathrm{z}$ odcinka $\mathrm{z}$ zacytowaną wypowiedzią danego bohatera, pojawiające się zawsze $\mathrm{w}$ trakcie emisji w telewizji, zdjęcia z planu, które zazwyczaj pojawiały się na profilu do południa lub po południu, jeszcze przed emisją odcinka, memy stworzone $\mathrm{z}$ użyciem scen $\mathrm{z}$ serialu, publikowane również najczęściej w godzinach przedpołudniowych lub w weekendy, posty przypominające o nowym odcinku lub sezonie, udostępniane niedługo przed emisją sezonu lub odcinka, zwiastuny nowych odcinków, pojawiające się w weekendy, zaproszenia na nowe odcinki, dodawane zwłaszcza przed rozpoczęciem trzeciego sezonu, pytania z wiedzy o serialu, np. „Gdzie Asia pierwszy raz zobaczyła Piotra?”, głosowania, m.in. na ulubiony wątek tygodnia lub decydujące o najlepszej partnerce dla głównego bohatera, a także filmiki zatytułowane moments, które pojawiały się w trakcie napisów końcowych w telewizji - zazwyczaj był to pierwszy post publikowany każdego dnia, od wtorku do piątku. Ponadto pojawiały się także materiały związane $\mathrm{z}$ wprowadzaniem do serialu nowych bohaterów, jak również z różnego rodzaju okolicznościami, np. życzenia urodzinowe dla aktorów z obsady lub informacje związane z Wielką Orkiestrą Świątecznej Pomocy.

Posty, które wywoływały najwyższe aktywności użytkowników, to najczęściej te związane z głosowaniami lub pytaniami z wiedzy o serialu. Zdjęcie z pytaniem: „Koło kogo powinien obudzić się Piotr?” i trzema możliwościami do wyboru osiągnęło w ciągu trzech dni prawie 4 tysiące komentarzy, a kadr $\mathrm{z}$ odcinka, w którym główni bohaterowie mieli się zaręczyć, z pytaniem: „Co odpowie Asia?”, osiągnął w dniu publikacji prawie 1,3 tysiąca komentarzy. Ponadto zwiastuny nowych odcinków również wywoływały bardzo wysokie aktywności, zazwyczaj przez weekend wyświetlało je od 55 do 75 tysięcy użytkowników (jeden ze zwiastunów, który zapowiadał odcinki finałowego tygodnia drugiego sezonu, zanotował nawet 84 tysiące wyświetleń i 458 komentarzy w ciągu dwóch dni). Z obserwacji wynika wniosek, iż wysokie zaangażowanie przypada też na posty, w których obecni byli serialowi Asia i Piotr.

Zazwyczaj publikowane posty osiągały kilka tysięcy polubień, najczęściej w dniu publikacji nie przekraczały progu 10 tysięcy lajków, udostępniane filmiki przeciętnie osiągały około 15-20 tysięcy wyświetleń, a pod materiałami, do których zaliczyłabym m.in. ujęcia z planu zdjęciowego, widniało od kilkunastu do kilkudziesięciu komentarzy. Sytuacja ta nie ulegała większym zmianom, nawet podczas wzrostu liczby obserwujących profil. 
Nawiązując do liczby obserwatorów, w połowie października 2019 roku wynosiła ona 91 tysięcy użytkowników, a pod koniec obserwacji, 11 marca 2020 roku, przekroczyła 120 tysięcy. Tempo przyrostu osób, które obserwowały profil, było zmienne, np. od końca października do końca listopada 2019 roku przybyło ponad 10 tysięcy widzów, natomiast zdobycie kolejnych 10 tysięcy trwało już prawie dwa miesiące.

Podczas obserwacji konta Zakochanych po uszy zostały zorganizowane dwie transmisje na żywo. W ramach jednej z nich, mającej miejsce 21 listopada, wystąpili aktorzy grający role serialowych Pauli oraz Pawła, a w drugiej, 18 grudnia, aktorka odgrywająca rolę Sylwii. Użytkownicy serwisu mogli zadawać aktorom pytania (zarówno w komentarzach, jak i w trakcie trwania transmisji), na które ci odpowiadali.

Analizując liczbę publikowanych postów, od poniedziałku do czwartku, przed emisją odcinków w telewizji, na profilu udostępnianych było przeciętnie od 2 do 9 postów. Z obserwacji wynika, iż więcej materiałów pojawiało się, kiedy zbliżał się finał drugiego sezonu serialu oraz na początku emisji trzeciego. Podczas odcinka publikowane były zazwyczaj trzy posty, najczęściej dwa przed blokiem reklamowym i jeden w trakcie lub po, pod koniec odcinka. W piątki publikowano 2-3 posty, wśród których często znajdował się zwiastun odcinków kolejnego tygodnia oraz filmik z napisów kończących odcinek poprzedniego dnia. Zdarzało się, iż w soboty oraz niedziele nie publikowano żadnych postów, a jeżeli coś się pojawiało, to często były to memy lub głosowanie na najlepszy wątek tygodnia. W okresie, w którym nastąpiła przerwa między emisją sezonu drugiego oraz trzeciego w telewizji, trwająca trzy tygodnie (aż do wznowienia moich obserwacji) - na profilu zostały w sumie opublikowane 33 posty. Treści udostępniane w tym czasie miały więcej wyświetleń niż te, które pojawiały się razem z odcinkami - filmiki miały często ponad 50 tysięcy wyświetleń, prawie wszędzie było też po kilkadziesiąt komentarzy.

Podczas emisji odcinków w telewizji posty, które były publikowane, na bieżąco komentowano oraz lajkowano, jednak były to aktywności niewielkie względem liczby obserwujących profil. Liczba lajków zazwyczaj nie przekraczała tysiąca, a komentarzy najczęściej było mniej niż 10. Pod koniec odcinka, a zarazem po bloku reklamowym, liczby te rosły, często do około 2 lub 3 tysięcy lajków i kilkunastu albo kilkudziesięciu komentarzy, w zależności od posta.

W instastory treści pojawiały się rzadko i nieregularnie. Jeżeli już miało to miejsce, $\mathrm{z}$ reguły było to przekierowanie do artykułu dotyczącego serialu, zamieszczonego na stronie www.tvn.pl. Czasami zdarzały się także ankiety z pytaniami dotyczącymi fabuły, m.in. „Czy Paula powinna przyjąć oświadczyny?”. Na początku marca zostały tam również opublikowane materiały video z aktorami odgrywającymi główne role, którzy zachęcali do oglądania TVN 7.

Najmniejszą aktywność zaobserwowałam pod materiałami, które w żaden sposób nie nawiązywały do fabuły serialu, były to m.in. filmiki zachęcające do oglądania TVN 7, gdzie pojawiło się zaledwie kilka komentarzy, lub post dotyczący WOŚP, który osiągnął niecałe 10 tysięcy wyświetleń i jeden komentarz. 
W poniższej tabeli zestawione zostały wyżej opisane rezultaty obserwacji.

Tabela 1. Rezultaty obserwacji nieuczestniczącej profilu instagramowego Zakochanych po uszy

\begin{tabular}{|c|c|c|c|}
\hline & $\begin{array}{l}\text { 16.10-19.12.2019 } \\
\text { (regularna obserwacja, } \\
\text { emisja drugiego sezonu } \\
\text { w telewizji) }\end{array}$ & $\begin{array}{l}\text { 20.12.2019-6.01.2020 } \\
\text { (przerwa w obserwa- } \\
\text { cji, przerwa w emisji } \\
\text { serialu) }\end{array}$ & $\begin{array}{l}7.01-11.03 .2020 \\
\text { (powrót do obserwacji, } \\
\text { emisja trzeciego sezonu } \\
\text { w telewizji) }\end{array}$ \\
\hline $\begin{array}{l}\text { Wzrost liczby } \\
\text { obserwujących }\end{array}$ & $\begin{array}{l}\text { Ponad } 91000 \rightarrow \text { ponad } \\
106000\end{array}$ & $\begin{array}{l}\text { Ponad } 106000 \rightarrow \\
\text { ponad } 110000\end{array}$ & $\begin{array}{l}\text { Ponad } 110000 \rightarrow \\
\text { ponad } 120000\end{array}$ \\
\hline $\begin{array}{l}\text { Liczba publikowanych } \\
\text { postów }\end{array}$ & $\begin{array}{l}\text { w ciągu tygodnia: ok. } \\
6-10 \text { postów dziennie; } \\
\text { w weekendy: } 0-3 \\
\text { postów }\end{array}$ & $\begin{array}{l}33 \text { nowe posty przez } \\
\text { cały ten okres }\end{array}$ & $\begin{array}{l}\text { w ciągu tygodnia: ok. } \\
\text { 6-13 postów dziennie } \\
\text { (najwięcej na początku } \\
\text { sezonu); } \\
\text { w weekendy: 0-3 } \\
\text { postów }\end{array}$ \\
\hline $\begin{array}{l}\text { Przeciętna liczba } \\
\text { reakcji pod postami } \\
\text { z początku emisji } \\
\text { odcinka }\end{array}$ & $\begin{array}{l}\text { 400-700 lajków, } \\
\text { 2-10 komentarzy }\end{array}$ & - & $\begin{array}{l}\text { 300-1000 lajków, } \\
\text { 2-15 komentarzy }\end{array}$ \\
\hline $\begin{array}{l}\text { Przeciętna liczba } \\
\text { reakcji pod postami po } \\
\text { bloku reklamowym, na } \\
\text { koniec emisji odcinka }\end{array}$ & $\begin{array}{l}\text { 1000-2000 lajków, } \\
10-25 \text { komentarzy }\end{array}$ & - & $\begin{array}{l}\text { 1000-3000 lajków, } \\
\text { 3-30 komentarzy }\end{array}$ \\
\hline $\begin{array}{l}\text { Post o najwyższej } \\
\text { aktywności }\end{array}$ & $\begin{array}{l}\text { Głosowanie na } \\
\text { najlepszą partnerkę dla } \\
\text { głównego bohatera - } \\
\text { ponad } 10000 \text { lajków, } \\
\text { prawie } 4000 \\
\text { komentarzy (publiko- } \\
\text { wane: } 22.11 \text { ) }\end{array}$ & - & $\begin{array}{l}\text { Zdjęcie z pytaniem, } \\
\text { co odpowie główna } \\
\text { bohaterka na } \\
\text { oświadczyny - ponad } \\
10200 \text { lajków, prawie } \\
1300 \text { komentarzy } \\
\text { (publikowane: } 15.01 \text { ) }\end{array}$ \\
\hline $\begin{array}{l}\text { Post o najniższej } \\
\text { aktywności }\end{array}$ & $\begin{array}{l}\text { Post przypominający } \\
\text { o odcinku - ponad } \\
6000 \text { lajków, } \\
0 \text { komentarzy } \\
\text { (publikowany: } 18.12 \text { ) }\end{array}$ & - & $\begin{array}{l}\text { Post o WOŚP - ponad } \\
9000 \text { wyświetleń, } 1 \\
\text { komentarz } \\
\text { (publikowany: 12.01) }\end{array}$ \\
\hline Transmisje live & $2(21.11$ oraz 18.12$)$ & - & 0 \\
\hline
\end{tabular}

Po analizie zebranego materiału doszłam do wniosków, które umożliwiły mi przejście do kolejnego etapu badań, czyli wywiadu swobodnego pogłębionego. Dzięki przeprowadzonej obserwacji otrzymałam pewien obraz prowadzenia profilu, odkryłam nowe elementy badanej rzeczywistości, jednak bez przypisanych jej znaczeń. Co za tym idzie, pojawiło się sporo pytań, które chciałam zadać osobie odpowiedzialnej za tworzenie strategii w social mediach, aby móc zestawić informacje, które od niej otrzymam, z moimi obserwacjami. 


\subsection{Analiza wyników wywiadu swobodnego pogłębionego - drugi etap badań}

Posłużenie się wywiadem swobodnym pogłębionym było zasadniczym źródłem informacji potrzebnych do odpowiedzi na postawione w pracy pytania badawcze. Rozmowę przeprowadziłam z Kingą Beśką (rozmówczyni wyraziła zgodę na posługiwanie się jej nazwiskiem w pracy, przy cytatach będzie oznaczona inicjałami $\mathrm{KB}$ ), menedżerką do spraw social mediów, która zarządza formatem Zakochani po uszy w telewizji TVN i jest odpowiedzialna m.in. za prowadzenie konta instagramowego, którego obserwacji się podjęłam. Wywiad odbył się 9 kwietnia 2020 roku za pośrednictwem internetowego komunikatora Messenger. Rozmowa trwała godzinę i 15 minut, została nagrana oraz przetranskrybowana. Interpretacja wywiadu była inspirowana teorią ugruntowaną. Zgodnie z ujęciem Moniki Kostery oraz Pawła Krzyworzeki (2012, s. 180) sposób ten pozwala sformułować teorie skoncentrowane na wycinkach rzeczywistości. Do analizy wykorzystałam kodowanie, zdefiniowane przez Kathy Charmaz (2013, s. 9) jako „opatrywanie poszczególnych segmentów danych etykietą opisującą ich zawartość”, które pozwala na „zobaczenie danych w sposób skoncentrowany" (Charmaz, 2013, s. 96). Materiał zgromadzony w tej części badania umożliwił szczegółowe zapoznanie się z tworzeniem strategii na Instagramie, która ma kreować więzi z widzami serialu od momentu jego powstania.

Rozpoczęcie prowadzenia profili w mediach społecznościowych Zakochanych po uszy wiązało się z odgórnie przyjętą strategią telewizji TVN, zgodnie z którą nowo powstałe programy oraz seriale powinny mieć konta w serwisach Facebook oraz Instagram. Takie działanie pozwala na dotarcie do pierwszych widzów i promocję formatu jeszcze przed emisją.

To jest część, która towarzyszy każdemu formatowi, kiedy się zaczyna. Jak się dowiadujemy, że wchodzi na antenę nowy format, to od razu zakładamy mu Instagram i Facebook, (...) żeby zbierać już grupę odbiorców, i tak naprawdę zanim ruszy serial, to przez dwa, trzy, cztery miesiące już hula Instagram i Facebook (KB).

Zdobywanie obserwujących na Instagramie, którzy mogli być potencjalnie zainteresowani oglądaniem serialu po jego premierze w telewizji, odbywało się przede wszystkim przy pomocy profili innych formatów TVN-u w tym serwisie społecznościowym. Aspektem, który ułatwiał powyższy proces, była docelowa grupa odbiorców, do której kierowany miał być serial, czyli ludzie młodzi, którzy często korzystają z social mediów i chętnie obserwują różne profile.

To robimy przez inne profile, które mają dużo obserwujących, czyli na tvn.pl były wrzucane zajawki, że będzie taki nowy serial, plus (...) żeby zbierać obserwatorów nowych seriali, stworzyliśmy follow Friday, czyli co piątek na Instagramie tvn.pl pojawiała się grafika z jakimś profilem, do którego obserwowania zachęcamy (...), dotarliśmy do tych ludzi też przez [program] 19+, dlatego że 19+ to są młodzi ludzie, jest robiony w Krakowie (...), ma bardzo dużo obserwatorów i zainteresowanie nie maleje, więc nagrywaliśmy z aktorami 
z 19+ zapowiedzi, że również w Krakowie, po sąsiedzku, będzie się odbywała taka i taka produkcja $(\mathrm{KB})$.

Podejmowanie decyzji o tym, jaki rodzaj postów ma być publikowany na profilu instagramowym Zakochanych po uszy oraz w jakim stylu prowadzić profil, od początku należało w sporej mierze do mojej rozmówczyni. Poza standardami, które muszą zostać spełnione przy każdym formacie, co wynika z odgórnie przyjętych w organizacji zasad, dotyczących np. zaproszeń na emisję pierwszych odcinków lub życzeń świątecznych dla widzów, Kinga Beśka mogła wykazać się kreatywnością oraz dowolnością. Po sprawdzeniu, które posty osiągają zainteresowanie odbiorców, możliwe było wykształcenie pewnej rutyny, wspomagającej utrzymanie silnych więzi z widzami.

Ja mam taką strategię, że jak codziennie rano siadam do Zakochanych po uszy, to najpierw wysyłam cytaty (...) i jak już [je] zrobię, to wtedy robię przedpremierowy zwiastun z jakimś fragmentem $\mathrm{z}$ odcinka, (...) a jednocześnie tak co dwie godziny staram się wrzucać jakieś posty, czyli zwykle są to zdjęcia z odcinka i mówię: „w dzisiejszym odcinku zdarzy się to i to", czasami zrobię też jakiś śmieszny mem, jeżeli zainspiruje mnie do tego fotos $(\mathrm{KB})$.

Liczba publikowanych postów na Instagramie zależy m.in. od ważności odcinka, który danego dnia jest emitowany w telewizji. Moja rozmówczyni przyznała, iż często jest obecna na planie zdjęciowym podczas nagrań scen uznawanych za ważne, aby zbierać materiał, którym przed premierą będzie mogła zainteresować odbiorców w social mediach. Jako przykład takiej sceny podała m.in. wypadek siostry głównego bohatera. Istotnym wyznacznikiem są jednak przede wszystkim godziny aktywności grupy odbiorców. Docieranie do widzów Zakochanych po uszy jest najłatwiejsze w godzinach popołudniowych oraz wieczornych, co także decyduje o częstotliwości i ilości publikowanego materiału.

Jeżeli ja targetuję np. grupę szkolną, to wiem, że najwięcej osób będzie na Instagramie o godzinie 16.00 , czyli wtedy, kiedy wracają ze szkoły, a później od 18.00 do 20.00. To jest taka godzina, o której jest największa aktywność i w telewizji, i w Internecie. (...) No i rzeczywiście na Instagramie też te godziny wieczorne są najbardziej oblegane i ja wiem, że zasięgi postów są wtedy największe. Najmniej sprawdzają mi się godziny poranne, więc jak już sprawdziłam, jakie zasięgi mają moje posty, to pierwszy post wrzucam o 11.00, dlatego że wcześniej się to nie sprawdza i wtedy nikt tego nie lajkuje i nie komentuje (KB).

Częste publikowanie treści na Instagramie wpływa na zainteresowanie widzów poszczególnymi postami. Jeżeli materiały udostępniane są wiele razy w ciągu dnia, zaangażowanie odbiorców się rozkłada. Powodem jest tutaj w szczególności algorytm omawianego serwisu społecznościowego, który wyświetla użytkownikom posty o największych zasięgach. Wobec powyższego moja rozmówczyni podjęła decyzję m.in. o ograniczeniu publikowanych cytatów w trakcie emisji odcinka z czterech do dwóch. Zapytana o rezultaty udostępniania ponadprzeciętnej liczby postów, odpowiedziała: 
Wydaje mi się, że zasięgi się wtedy rozchodzą, że są mniejsze jednak. No bo to też jest związane z polityką Instagrama, który wprowadził to, że nie wszystko ci się wyświetla na tablicy (...) Ja bym tak ostrożnie powiedziała, że za dużo postów też nie jest dobrze (KB).

Zarządzanie relacjami z widzami serialu telewizyjnego przy pomocy serwisu Instagram uwzględnia także dobór odpowiedniego słownictwa oraz wydawanie konkretnych, sprecyzowanych poleceń w przekazywanych komunikatach w celu zachęcenia odbiorcy do interakcji i wyrażenia swoich opinii. Istotne jest, by w postach kłaść nacisk na zadawanie pytań zamiast używania trybu rozkazującego. Ponadto, pomimo zaleceń, które moja rozmówczyni odnajdywała w wielu poradnikach, aby zwracać się do obserwatora w liczbie pojedynczej, z jej obserwacji wyniknęły odmienne wnioski.

To weszło do naszych zasad, że na Instagramie zwracamy się do masy, czyli jest jakaś grupa i mówimy do was „wy”. (...) Uważam, że to bardzo wpływa na aktywność, bo jak czytasz post np.: „Napisz, jaka jest twoja ulubiona postać z serialu”, to mam wrażenie, że obserwator się krępuje i jest dużo mniej komentarzy, niż kiedy napiszesz: „Jaka jest wasza ulubiona?". Wtedy obserwator nie czuje, że to konkretnie on jest pytany i jak gdyby wywoływany do tablicy. (...) No i ludzie chętniej komentują takie posty, gdzie mają jasne instrukcje i niewiele to od nich wymaga, czyli wrzucenia emotki (KB).

Podczas tworzenia strategii, która zakłada kreowanie więzi z odbiorcami, jak również docieranie do nowych obserwatorów, kwestią sporną okazało się używanie w postach hashtagów. Na początku funkcjonowania serwisu Instagram były one bowiem sposobem na wyszukiwanie ciekawych profili, a osoby chcące wypromować swoje konta, dodawały do publikowanych materiałów wiele takich znaczników, niejednokrotnie niezwiązanych z treścią postów. W momencie wzrostu liczby użytkowników Instagrama takie działanie przestało spełniać pierwotną funkcję, gdyż najpopularniejsze hashtagi zaczęły być przepełnione treściami, udostępnianymi niemal w każdej sekundzie. Z tego względu, przy prowadzeniu mediów społecznościowych serialu, moja rozmówczyni ogranicza używanie tego typu znaczników do kilku: \#zakochanipouszy, \#siódemka (który zastąpił \#tvn7, ponieważ aktualną wizją telewizji TVN jest postrzeganie tego kanału jako odrębnej stacji, co skutkowało m.in. zmianą nazewnictwa) lub \#emocjebudząemocje - hashtag nawiązujący do wizerunkowego hasła Siódemki.

Zawsze wprowadzam \#zakochanipouszy, bo chcę nauczyć ludzi, że jak wrzucają coś z Zakochanymi po uszy, to idzie potem ten ogólny hashtag, żeby ludzie nie zgubili tego (...), są standardowe hashtagi (...), ale to tylko i wyłącznie dlatego, żeby opisać i dodać emocji czy wprowadzić jakiś klimat, ale już nie po to, żeby zwiększyć sobie zasięgi czy coś (KB).

Najwyższe aktywności użytkowników, zgodnie z opisywanymi (po zakończonej obserwacji nieuczestniczącej) tendencjami, wywołują posty, w których widzowie mogą wykazać się wiedzą na temat serialu, czyli wyróżnione przeze mnie quizy oraz głosowania, w wypadku których otrzymują m.in. możliwość wyboru najlepszego wątku danego tygodnia, najlepszej partnerki dla głównego bohatera czy 
przewidywań dalszych losów serialowych postaci. Ponadto największe zasięgi uzyskują także memy tworzone z wykorzystaniem ujęć z odcinków.

To jest największy zasięg, takie memy, bo to ludzie podają dalej, odsyłają sobie, komentują: „Ha, ha, to ja” i jakieś takie rzeczy. Jeżeli chodzi o komentarze, to (...) wszystkie głosowania cieszą się największym zainteresowaniem. Ja też robiłam takie quizy, wiadomo, że quizy muszą być łatwe, czyli: „Jak nazywa się ten piesek?” (...) i wiadomo, że każdy zna odpowiedź, dlatego chciałby się pochwalić, że zna i jest takim superfanem, i pisze (KB).

Posty, które nie cieszą się wysoką aktywnością odbiorców, to przede wszystkim treści sponsorowane, wykupione przez oficjalnego partnera Zakochanych po uszy producenta karmy Purina. Mimo że jest to niewielki procent spośród wszystkich materiałów udostępnianych na serialowym profilu (około 10 postów rocznie), odbiegają one od standardowego, swobodnego stylu pisania, charakterystycznego dla publikowanych treści.

To się spotyka z ogromną dezaprobatą obserwatorów, bo nie pasuje w ogóle do profilu i widać, że to jest sponsorowane, a ludzie nie lubią, jak widać jakieś lokowania (...) Ja też nie chcąc się narażać obserwatorom - takie posty, które muszę wrzucać konkretnego dnia, wrzucam $\mathrm{z}$ rana, np. o 7 rano $(\mathrm{KB})$.

Komentarze, które pojawiają się pod postami, oprócz odpowiedzi na zadawane pytania o ulubione postaci i wątki, często zawierają sugestie dotyczące fabuły, spostrzeżenia na temat zachowań poszczególnych bohaterów, a także - jako przykład wyrażanie opinii, że niektórzy z nich powinni lub nie powinni być razem. Głosy te są ważne dla produkcji serialu, jednak nie jest możliwe, aby miały one bezpośredni wpływ na powstający scenariusz, ponieważ odcinki nagrywane są ze sporym wyprzedzeniem względem tych emitowanych w telewizji. Mimo to, przyglądając się uwagom widzów w social mediach, moja rozmówczyni może próbować zmieniać ich nastawienie, podejmując odpowiednie kroki.

Często produkcja zwraca się do mnie i pyta, jak wygląda sytuacja. I ja np. im mówię: „Rzeczywiście, te nowe wątki nie podpasowały, nie podoba im się to", ale to nie wpływa na scenariusz, bo wiadomo, że jak w emisji jest 100. odcinek, to nagrywany jest już 150., więc nie da się realnie na to wpłynąć. (...) Ale wtedy ja zmieniam strategię na Instagramie, że np. staram się nie pokazywać tych postaci albo ocieplać ich wizerunek (...) i rzeczywiście to bardzo wpływa. (...) Albo staram się naprawdę uczestniczyć w tych rozmowach w komentarzach czy odpowiadać na potrzeby obserwatorów, np. wrzucam post i mówię słuchajcie, zdajemy sobie sprawę z tego, że jest dużo nowych postaci i wątków, ale dajcie nam szansę $(\mathrm{KB})$.

Pojawienie się w trzecim sezonie nowych postaci i wątków, o których wspominała Kinga Beśka, było jednym z aspektów, przez które oglądalność serialu spadła, ponieważ część widzów sugeruje, iż są one wymuszone. Ponadto przez wzrost popularności serwisów filmowych, takich jak Netflix lub HBO GO, zainteresowanie polskimi produkcjami maleje. Spadek oglądalności Zakochanych po uszy wiąże się 
również z mniejszą aktywnością użytkowników profilu serialu na Instagramie. Jednakże moja rozmówczyni zauważa, że oglądalność rośnie, kiedy stara się „nakręcić” emocjonalnie odbiorców i przygotować ich, że w danym odcinku wydarzy się coś ważnego.

Jak jest jakaś wysoka oglądalność, to ja mówię: „He, he, to właśnie dlatego, że ja strasznie "grzałam» tym odcinkiem", bo rzeczywiście czasami są takie odcinki, które ja specjalnie „grzeję”, bo ludzie np. mogą nie być świadomi, że coś fajnego się teraz dzieje (...). I rzeczywiście, wtedy widzimy, że jest lepsza oglądalność, bo ludzie są nastawieni na to, że $\mathrm{w}$ tym odcinku będzie się działo (KB).

Wobec powyższego wykorzystanie marketingu społecznościowego do zarządzania relacjami z widzami pozwala budować świadomość otoczenia, że dany serial jest emitowany oraz co się w nim dzieje i jakie zdanie mają na jego temat inni odbiorcy. Dodatkowo, dzięki publikowanym w social mediach materiałom zza kulis, relacje widzów z aktorami występującymi w serialu, a także całą produkcją, stają się silniejsze.

Dużo większa więź się tworzy, kiedy ludzie widzą backstage tego wszystkiego na Instagramie, mogą zobaczyć, jak to jest tworzone, jak się zachowują aktorzy tak naprawdę, że dużo więcej materiałów jest pokazywanych na Instagramie niż w odcinku, że są jakieś dodatkowe rzeczy, i to ich mobilizuje i przez to też się taka więź tworzy. Wydaje mi się, że to jest megaważne teraz $(\mathrm{KB})$.

Przytoczone tendencje wraz z omówioną strategią zarządzania mediami społecznościowymi zostały zestawione $\mathrm{z}$ danymi statystycznymi pochodzącymi z serialowego Instagrama oraz wynikami oglądalności Zakochanych po uszy w celu pogłębienia analizy badanych zjawisk.

\subsection{Analiza danych zastanych - trzeci etap badań}

Po przeprowadzeniu wywiadu swobodnego pogłębionego Kinga Beśka udostępniła mi statystyki z profilu Zakochanych po uszy na Instagramie, a także statystyki oglądalności serialu na początku pierwszego sezonu oraz pod koniec emisji trzeciego. Analiza powyższych danych umożliwiła wyszczególnienie długookresowych trendów związanych z wykorzystaniem marketingu społecznościowego do zarządzania relacjami $z$ widzami serialu oraz jego produkcją.

Według statystyk pochodzących z profilu serialowego w serwisie Instagram 12 kwietnia 2020 roku liczba obserwujących wynosiła 125909 użytkowników. Najpopularniejsze lokalizacje, z których pochodzili, to: Warszawa (4\%), Kraków (3\%) oraz Łódź (2\%). Wśród obserwatorów znalazło się 93\% kobiet oraz 7\% mężczyzn. Zgodnie z informacją uzyskaną od mojej rozmówczyni podczas wywiadu - na początku prowadzenia konta odsetek mężczyzn obserwujących profil wynosił zaledwie $1 \%$, jednak powyższa tendencja może wynikać ze scenariusza serialu. 
Zastanawialiśmy się, co możemy zrobić, żeby dotrzeć do mężczyzn za pomocą tego profilu, ale to było niewykonalne, dlatego że serial jest o miłości i tam rzeczywiście na początku grało naprawdę mało mężczyzn, zresztą jest taki ckliwy (KB).

Obserwatorzy badanego konta to w większości osoby z grupy docelowej, do której kierowany jest serial, czyli ludzie młodzi z przedziału wiekowego od 18 do 24 lat (43\%). W ciągu tygodnia, od 5 do 12 kwietnia, na profilu został odnotowany wzrost liczby odbiorców o 1178 osób. Prawie 65 tysięcy użytkowników odwiedziło w tym czasie profil (było to ponad 15 tysięcy osób mniej niż w okresie od 29 marca do 4 kwietnia), a jego zasięgi wyniosły niecałe 164 tysiące (co oznaczało spadek o ponad 4 tysiące względem poprzedniego tygodnia).

Obraz 1. Liczba odbiorców (odkrywanie) Obraz 2. Interakcje z profilu instagramo-
profilu instagramowego Zakochanych po wego Zakochanych po uszy w okresie 5.04-
$\begin{array}{ll}\text { uszy w okresie 5.04-11.04.2020 } & 11.04 .2020\end{array}$

Odkrywanie (1)

Interakcje (1)

163675

Liczba odbiorców w okresie od 05.04 do 11.04

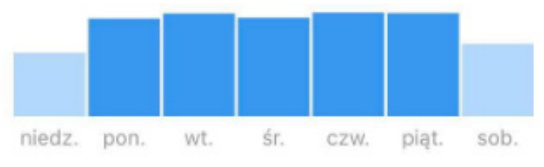

163675

Zasięg

-4269 vs. $29.03-4.04$

Wyświetlenia

2551773

-421139 vs. $29.03-4.04$

Kliknięcia przekierow
+3 vs. $29.03-4.04$

65070

Dzialania wykonane na koncie w okresie od 05.04 do 11.04

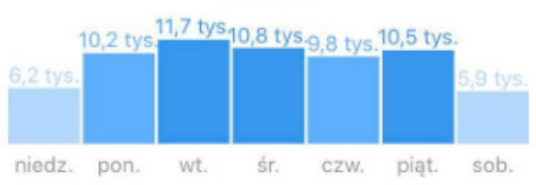

Wizyty w profilu

64962

-15451 vs. $29.03-4.04$

Kliknięcia przekierowujące do witryny

108

Źródło: statystyki z: https://www.instagram. com/zakochanipouszytvn7/.

Źródło: statystyki z: https://W
com/zakochanipouszytvn7/.

Post, który od początku prowadzenia konta osiągnął największy zasięg (128 tysięcy), to mem z serialowymi bohaterami, co potwierdza informacje uzyskane $\mathrm{w}$ trakcie wywiadu. Wysokie zasięgi przypadają także na materiał $\mathrm{z}$ ostatniego odcinka drugiego sezonu serialu oraz zdjęcie ze ślubu głównych bohaterów (oba posty uzyskały 114 tysięcy). Najczęściej komentowane były wspominane już głosowania, a lajkowane - zgodnie z wnioskami z obserwacji nieuczestniczącej - treści, które ukazywały serialowych Asię i Piotra.

Ze statystyk dostępnych pod przykładowymi, udostępnianymi instastories wynika, iż ogląda je mniej osób niż regularne posty publikowane na profilu. Przeciętne zasięgi, które osiągają materiały w instastories, wynoszą od 25 do 45 tysięcy. 
Obraz 3. Najczęściej lajkowane posty z profilu instagramowego Zakochanych po uszy

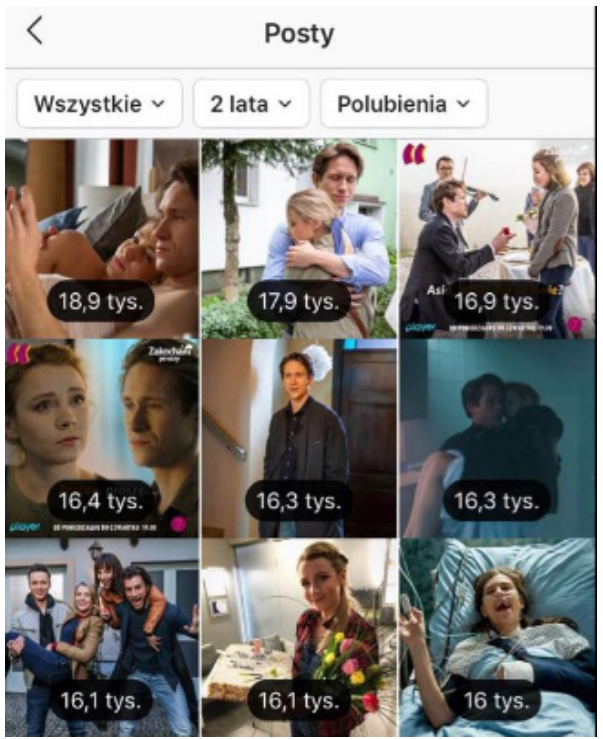

Źródło: statystyki z: https://www.instagram. com/zakochanipouszytvn7/.
Obraz 4. Najczęściej komentowane posty z profilu instagramowego Zakochanych po uszy

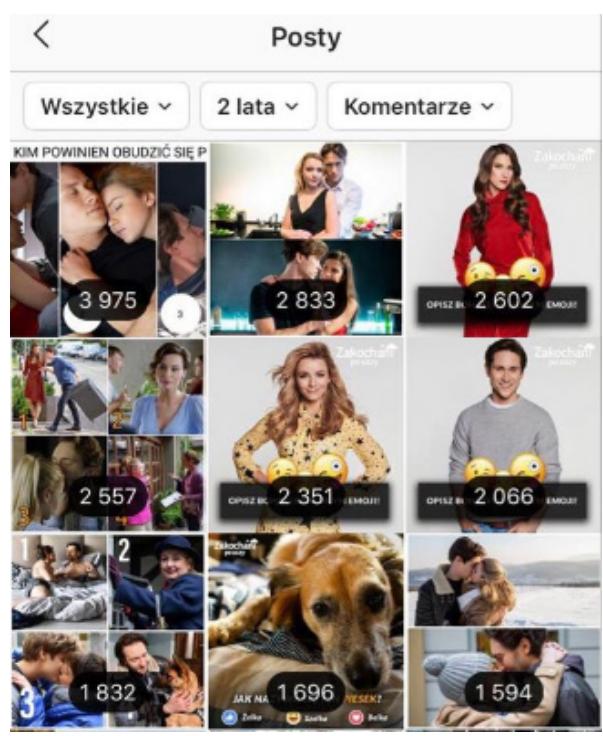

Źródło: statystyki z: https://www.instagram. com/zakochanipouszytvn7/.

Zgodnie z wypowiedziami mojej rozmówczyni podczas wywiadu - oglądalność pierwszego sezonu serialu była znacznie większa niż trzeciego, co widać w statystykach. Jednym z powodów, dla których taki stan rzeczy miał miejsce, jest m.in. fakt, iż pierwsze odcinki serialu emitowane były na kanałach TVN 7 oraz TVN w celach promocyjnych, a po miesiącu emisja została ograniczona tylko do pierwszego z nich. Z pozyskanych danych wynika, że udział grupy wiekowej 16-49 w oglądalności premierowego odcinka Zakochanych po uszy wynosił 10,1\%, po przejściu do TVN 7 spadł do około 6,9\%, a oglądalność trzeciego sezonu oscylowała między $3,5 \%$ a $5 \%$.

\subsection{Analiza wyników kwestionariusza ankiety - czwarty etap badań}

Ostatnim etapem badania było posłużenie się narzędziem ilościowym, jakim jest kwestionariusz ankiety. Badania nie miały charakteru reprezentatywnego. Ich celem była eksploracja opinii widzów na temat produkcji Zakochani po uszy oraz działań podejmowanych na profilu serialu w serwisie Instagram. Aby zapoznać się z opiniami potencjalnych widzów serialu, zadałam 11 krótkich pytań (dwa z nich dotyczyły płci oraz wieku respondenta), odpowiedzi miały potwierdzić lub zaprzeczyć założeniom przyjętym po analizie wyników badania jakościowego. Kwestionariusz 
został przygotowany za pomocą formularzy Google, a następnie, 28 kwietnia 2020 roku, umieszczony na moich prywatnych profilach w serwisach Facebook oraz Twitter. Na odpowiedzi czekałam do 8 maja. W badaniu wzięło udział 101 osób (78 kobiet oraz 23 mężczyzn). Ponad 75\% respondentów należało do przedziału wiekowego 18-24, w który wpisuje się także najwięcej obserwatorów profilu $\mathrm{Za}$ kochanych po uszy na Instagramie. Na wykresie przedstawiona została liczba osób z poszczególnych przedziałów wiekowych, które wzięły udział w badaniu.

\section{Wykres 1. Liczba respondentów z poszczególnych przedziałów wiekowych}

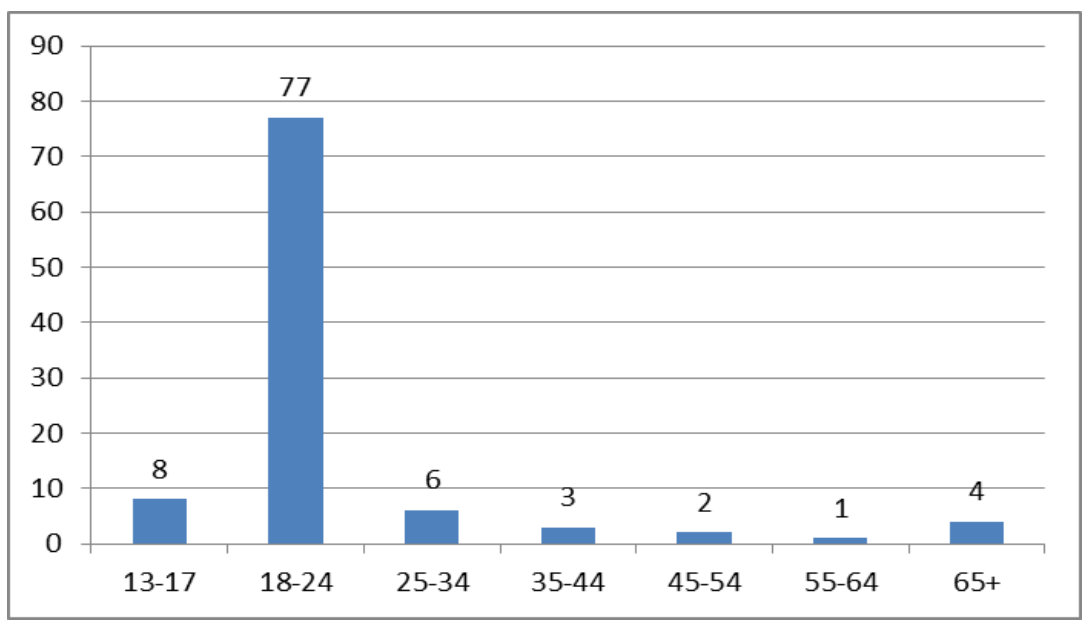

Źródło: opracowanie własne.

Pierwsze pytanie zamknięte brzmiało: „Czy kojarzy Pan/Pani serial Zakochani po uszy?”. Spośród wszystkich respondentów 65 osób udzieliło odpowiedzi „tak”, a 36 odpowiedziało „nie”. Wśród badanych, którzy zadeklarowali, iż w ogóle nie kojarzą wyżej wymienionej produkcji, znalazło się 14 mężczyzn i 22 kobiety, a ponadto $14 \mathrm{z}$ nich nie mieściło się w przedziale wiekowym 18-24. Respondenci, którzy nie znali badanego serialu, byli proszeni o odpowiedź na jeszcze jedno pytanie otwarte na końcu kwestionariusza.

Osoby, które odpowiedziały, iż znają Zakochanych po uszy, zostały zapytane, czy oglądają serial, a także skąd się o nim dowiedziały. Pomimo kojarzenia produkcji prawie połowa tej części respondentów (31 osób) nigdy nie oglądała serialu. Jedynie 8 badanych zadeklarowało, że robią to regularnie (były to kobiety między 17. a 29. rokiem życia), a 26 przyznało, że zdarza im się to czasami lub oglądali serial, ale przestali. Wśród nich znalazło się tylko 2 mężczyzn, jeden z nich dowiedział się o Zakochanych po uszy od swojej dziewczyny. 
Wykres 2. Opracowanie odpowiedzi na pytanie: „Czy ogląda Pan/i serial Zakochani po uszy?"

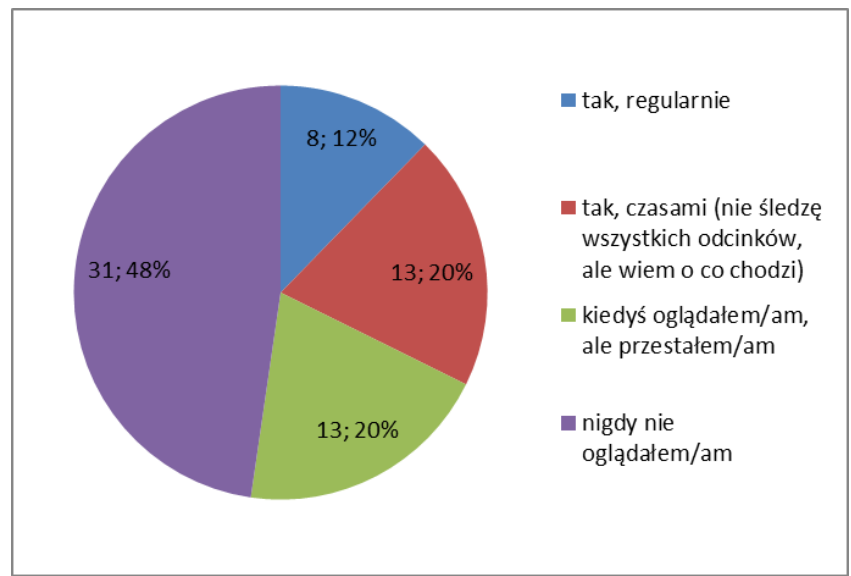

Źródło: opracowanie własne.

Przeważająca większość badanych kojarzących serial (54 osoby) dowiedziała się o nim z telewizji. Zaledwie 3 osoby zadeklarowały, iż znają produkcję z mediów społecznościowych. Pojawiły się także dodatkowe, pojedyncze głosy wskazujące za źródło informacji znajomych, plakaty reklamowe lub billboard w mieście czy produkcję serialu. Jeden $\mathrm{z}$ respondentów zdecydował się ominąć to pytanie.

Wykres 3. Opracowanie odpowiedzi na pytanie: „Skąd dowiedział/a się Pan/i o serialu Zakochani po uszy?"

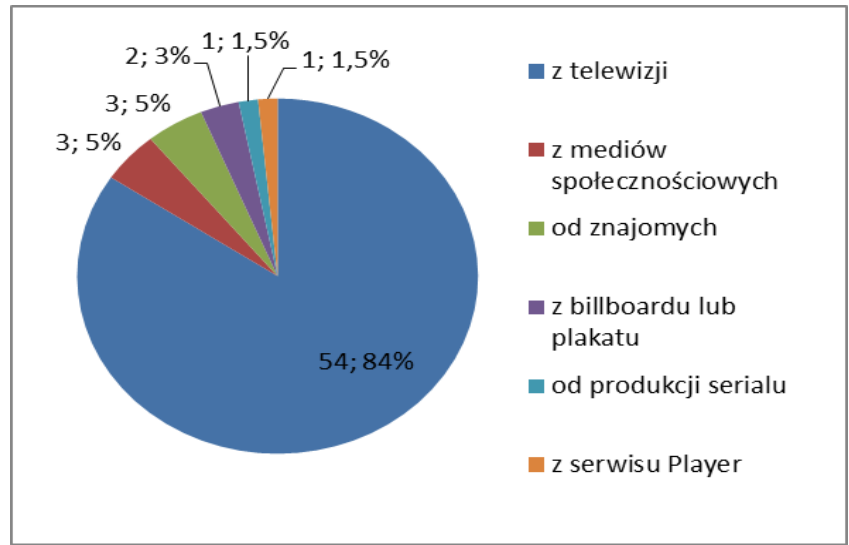

Źródło: opracowanie własne. 
Odpowiedzi na pytanie: „Czy obserwuje Pan/i profil Zakochanych po uszy na Instagramie?” wykazały, iż znacząca większość badanych (52 osoby) nigdy tam nie zaglądała. Jedynie 6 respondentów wskazało, że obserwuje badany profil (wyłącznie kobiety z przedziału 18-24), a 7, że nie należy do grona obserwujących, ale zdarza im się tam zaglądać.

Wykres 4. Opracowanie odpowiedzi na pytanie: „Czy obserwuje Pan/i profil Zakochanych po uszy na Instagramie?"

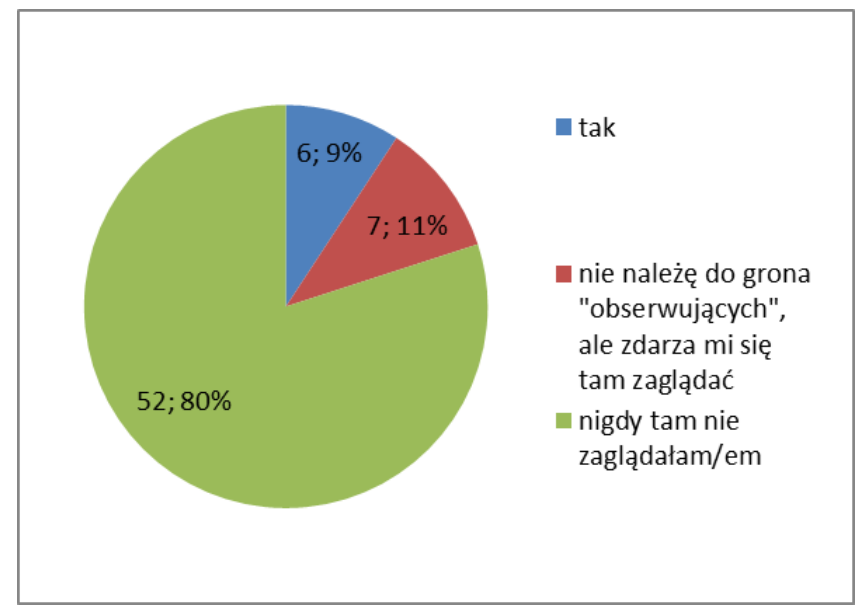

Źródło: opracowanie własne.

Osoby, które zadeklarowały, iż zdarzyło im się zaglądać na Instagram serialu lub nawet należą do grona obserwujących, były proszone o odpowiedzi na pytania: kiedy odwiedzają profil, w jakim celu to robią, jaką aktywność tam podejmują oraz które posty wzbudzają ich największe zainteresowanie. Pomimo relatywnie niewielkiej liczby respondentów w tej części pytań odpowiedzi okazały się bardzo zróżnicowane. Ponad połowa głosów dotyczących pory odwiedzin profilu (7 odpowiedzi) wskazywała chwilę przed, w trakcie lub po obejrzeniu odcinka. Inni dopisywali, iż robili to z ciekawości (m.in. chcąc sprawdzić, co to za serial, którego akcja toczy się w miejscu zamieszkania respondenta), przypadkiem lub kiedy nie emitowano nowych odcinków. Jedna z osób zdecydowała się ominąć tę część pytań. 
Wykres 5. Opracowanie odpowiedzi na pytanie: „Kiedy najczęściej zdarza się Pani/Panu zaglądać na profil instagramowy Zakochanych po uszy?”

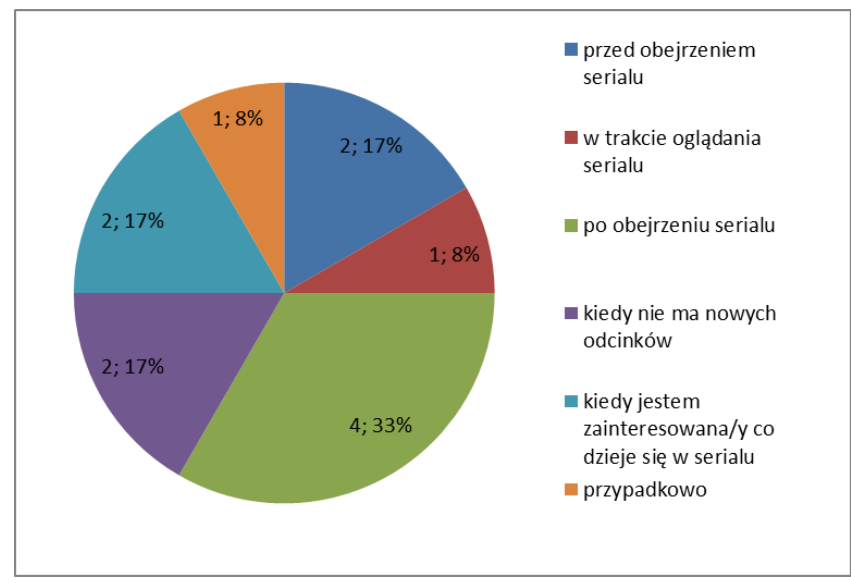

Źródło: opracowanie własne.

Cel odwiedzania konta, który przeważał wśród odpowiedzi respondentów (7 osób), to fakt, iż informacje tam publikowane są uzupełnieniem serialu telewizyjnego. Niektórzy wskazali także, że zaglądają na profil, żeby podyskutować z innymi użytkownikami na temat serialu lub poznać ich opinie (3 osoby) oraz aby przypomnieć sobie najciekawsze fragmenty odcinków (1 osoba). Jeden badany zajrzał tam również w celu sprawdzenia, co to za serial.

Wykres 6. Opracowanie odpowiedzi na pytanie: „W jakim celu odwiedza Pan/i profil Zakochanych po uszy na Instagramie?"

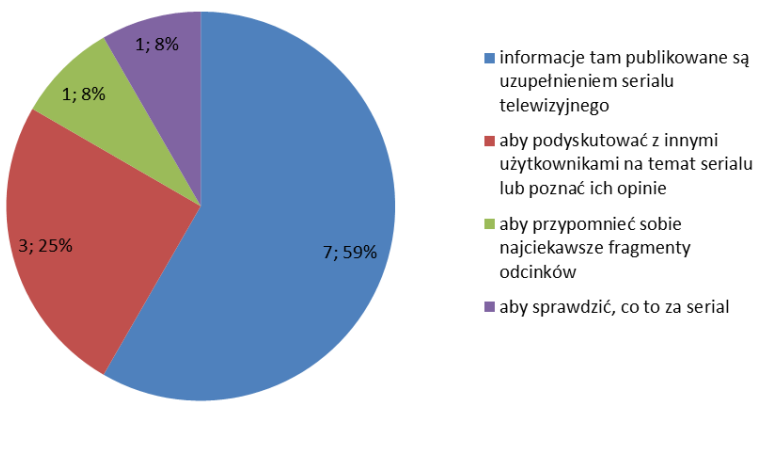

Żródło: opracowanie własne. 
Niemal wszystkie osoby, które wskazały, iż odwiedzają Instagram Zakochanych po uszy (11 odpowiedzi), określiły, że będąc tam, jedynie przeglądają profil lub lajkują posty, które im się podobają. Zaledwie jeden badany zadeklarował, iż często komentuje różne treści, odpowiada na ankiety, a także bierze udział w quizach.

Wykres 7. Opracowanie odpowiedzi na pytanie: „Kiedy zagląda Pan/i na profil Zakochanych po uszy, jaką aktywność Pan/i tam podejmuje?"

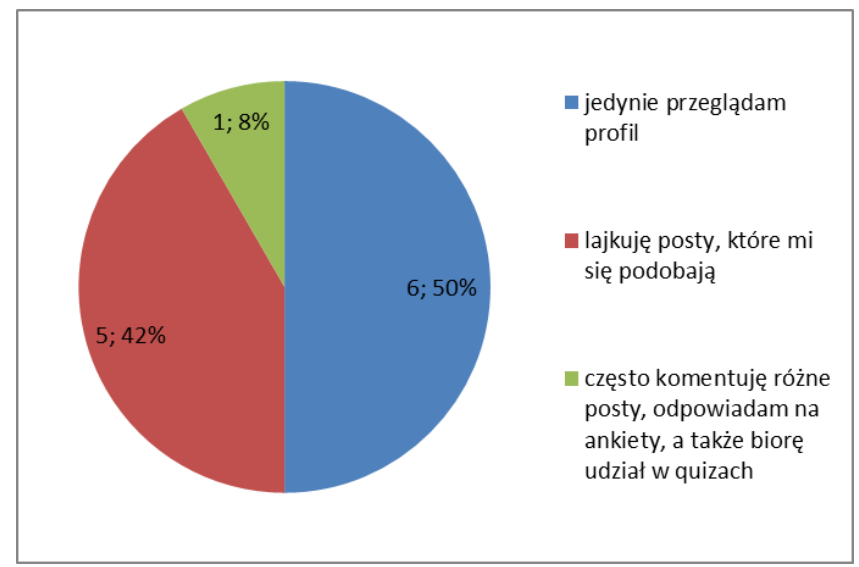

Żródło: opracowanie własne.

Według odpowiedzi na pytanie wielokrotnego wyboru największe zainteresowanie respondentów na Instagramie serialu budzą zwiastuny kolejnych odcinków, które wskazało 9 osób. Niemal tak samo interesujące okazały się zdjęcia i filmiki z planu (8 głosów), na trzecim miejscu znalazły się memy (6 głosów). Najmniej osób wykazało zainteresowanie cytatami z odcinków (4 głosy).

Wszyscy badani, niezależnie od znajomości produkcji Zakochani po uszy, zostali poproszeni o odpowiedź na jedno otwarte pytanie. Dotyczyło ono wyrażenia opinii na temat wykorzystania mediów społecznościowych przez telewizję (z naciskiem na tworzenie profili seriali lub programów telewizyjnych) w celu budowania relacji z odbiorcami. Znacząca większość respondentów (87 osób) oceniła wyżej wymienione działania pozytywnie. Jako argumenty wskazywali najczęściej pozyskiwanie dzięki tego typu profilom nowych widzów, umożliwienie odbiorcom zapoznania się z dodatkowymi materiałami i produkcją „od kuchni” oraz możliwość dyskusji na jej temat, przywiązanie do serialu oraz aktorów, którzy w nim grają, a także fakt, iż młodzi ludzie częściej spędzają czas w Internecie niż przed telewizorem, więc to właśnie stamtąd mogą dowiedzieć się o potencjalnie interesujących produkcjach. Niektóre osoby deklarowały, że same obserwują podobne profile, co 
zachęca ich do oglądania kolejnych odcinków, a nawet podsyca emocje względem serialu.

Cztery spośród badanych osób zwróciły uwagę na fakt, iż w Polsce wyżej wymienione działania nie sprawdzają się tak dobrze, jak wśród produkcji zagranicznych, wskazując za wzorcowy przykład serwis Netflix i jego social media. Pięciu respondentów przyznało, że nie ma na ten temat wyrobionego zdania, gdyż nie ogląda telewizji, nie śledzi podobnych profili lub nie zastanawiało się nad tym - żaden z nich nie kojarzył też produkcji Zakochani po uszy. Jedynie dwie osoby wyraziły negatywną opinię na temat wykorzystania mediów społecznościowych przez telewizję do budowania relacji z odbiorcami. Jedną z nich był 66-letni mężczyzna, którego odpowiedź brzmiała: „Nikt tego nie sprawdza”, nie znał on także badanego serialu. Drugą - 23-letnia kobieta, która uznała wyżej wymienione działania za zbędne i dodała: „szczególnie jeśli chodzi o polskie seriale tego typu, nie jest to potrzebne, bo ich odbiorcy to osoby, które czerpią informacje z telewizji, a nie social mediów". Trzech respondentów zdecydowało się nie odpowiadać na to pytanie, wpisując we wskazanym miejscu ukośnik.

\section{Omówienie wyników}

Po zakończeniu badań oraz ich interpretacji uzyskane wyniki zostały zestawione $\mathrm{z}$ treściami zawartymi w literaturze przedmiotu oraz omówione $\mathrm{w}$ kontekście znaczenia naukowego.

Nowe media stały się przestrzenią reklamy produktów telewizyjnych. Za Bogusławem Nierenbergiem (2015, s. 52) należy przyjąć, iż reklamy zlecone w konkretnych witrynach (run on site) oraz we wszystkich witrynach danej sieci handlowej (run on network) „służą na ogół zwiększaniu u odbiorców świadomości marki”. Dotarcie do grupy odbiorców serialu Zakochani po uszy było możliwe przede wszystkim dzięki publikowaniu informacji o nowym formacie na innych profilach stacji TVN w serwisach społecznościowych. Krzysztof Obłój i Maciej Trybuchowski (2006, s. 127) w swojej pracy zaprezentowali rozważania na temat strategii, którą uznali za jeden $\mathrm{z}$ fundamentalnych instrumentów zarządzania. Stworzenie strategii w mediach, która miała kreować silne więzi z widzami serialu Zakochani po uszy, przyczyniło się do sukcesu produkcji jeszcze przed premierą pierwszego sezonu.

Analiza danych zastanych oraz informacji pozyskanych $\mathrm{w}$ trakcie wywiadu swobodnego pogłębionego wykazała jednak spadek oglądalności trzeciego sezonu serialu, co szło w parze z mniejszym zaangażowaniem użytkowników na Instagramie pomimo wzrostu liczby obserwujących profil. Odwołując się do cyklu życia produktu, czyli techniki ukazującej „kolejne stadia rynkowego rozwoju konkretnego wyrobu" (Obłój, Trybuchowski, 2006, s. 155), omówionej przez wyżej wymienionych autorów, zaklasyfikowałabym Zakochanych po uszy do fazy spadku, która wiąże się ze stopniową utratą zdolności produktu do zaspokajania potrzeb 
nabywców (Obłój, Trybuchowski, 2006, s. 155-156). Pomimo tego, dzięki konwergencji mediów i wykorzystaniu marketingu społecznościowego do zarządzania relacjami z widzami, możliwe jest „przedłużenie rynkowego życia” serialu (Obłój, Trybuchowski, 2006, s. 155-156).

Obserwacja nieuczestnicząca oraz informacje uzyskane podczas wywiadu swobodnego pogłębionego wykazały, że przy wykorzystaniu marketingu społecznościowego do zarządzania relacjami z widzami techniki social $T V$, o których pisał Paweł Szews (2014, s. 67-68), są aktualne, a odbiorcy w mediach społecznościowych na bieżąco wyrażają swoje opinie na temat produkcji, komentując odcinki serialu także w trakcie ich oglądania. Wykorzystują w ten sposób multiscreening, opisywany przez Marzenę Barańską (2017, s. 786). Odpowiedzi pozyskane z kwestionariusza ankiety ujawniły, iż procent widzów obecnych na Instagramie Zakochanych po uszy może być relatywnie niewielki w porównaniu do liczby osób, które kiedykolwiek oglądały serial, jednakże znacząca większość respondentów była zdania, że współpraca telewizji i mediów społecznościowych jest zjawiskiem pozytywnym i potrzebnym. Potwierdza to teorię Pawła Szewsa (2014, s. 67-68), iż daje ona korzyści zarówno odbiorcom, którzy mogą komunikować się w ten sposób z osobami sławnymi, wyrażać swoje spostrzeżenia i zostać wysłuchani, jak i nadawcom, mającym możliwość dostosowania materiałów, jakie oferują, do potrzeb odbiorców.

Analiza rezultatów obserwacji nieuczestniczącej wykazała, iż kategorie udostępnianych na Instagramie postów, które wyszczególnili Yuheng Hu, Lydia Manikonda i Subbarao Kambhampati (2014, s. 595), nie były wystarczające, aby zakwalifikować do nich treści publikowane na profilu Zakochanych po uszy. Wobec powyższego sformułowane zostały nowe kategorie, umożliwiające scharakteryzowanie zawartości badanego konta.

Interpretacja wyników badań dowiodła, że tworzenie strategii w mediach społecznościowych przez produkcję Zakochanych po uszy wiąże się ze stosowaniem memejackingu, zdefiniowanego przez Angelikę Czajkowską (2020) jako wykorzystanie potencjału popularnych memów na potrzeby marki, której skuteczność potwierdzają wysokie zasięgi takich postów publikowanych na serialowym Instagramie. Istotną funkcję pełni także marketing kryzysowy, który według autorki „stanowi reakcję na zażalenia odbiorców lub inne negatywne sytuacje” (Czajkowska, 2020). Produkcja Zakochanych po uszy zetknęła się z niezadowoleniem widzów m.in. po wprowadzeniu w trzecim sezonie serialu nowych wątków oraz bohaterów. Działania podjęte w mediach społecznościowych pozwoliły na zmianę podejścia odbiorców, którzy obserwują profile serialu, i bardziej przychylne spojrzenie na nielubiane postaci.

Najbardziej zaskakującym rezultatem okazały się odpowiedzi na pytanie: „Skąd dowiedział/a się Pan/i o serialu Zakochani po uszy?", które pojawiło się w kwestionariuszu ankiety. Prawie $85 \%$ respondentów kojarzących produkcję wskazało jako źródło informacji telewizję, co zaprzecza tezie postawionej przez Annę Drab-Kurowską (2012, s. 180), jakoby media społecznościowe dostarczały informacji 
o wiele szybciej niż tradycyjne. Nie jest to również zgodne z założeniami przyjętymi po przeprowadzeniu wywiadu swobodnego pogłębionego, w którym Kinga Beśka opowiadała o docieraniu do widzów przez social media. Jednak może się to wiązać z tendencjami zaobserwowanymi przez Marka Szafarza, byłego dyrektora marketingu TVN Media, który w 2013 roku wyjaśniał, że Internet jest drugim (po autopromocji) źródłem czerpania informacji o programie telewizyjnym przez odbiorców (Pallus, 2013). Ponadto grupa respondentów, którzy wzięli udział w badaniu, w większości nie była zainteresowana badaną produkcją. Kwestia szybkości dostarczania informacji przez różne typy mediów powinna zostać przeanalizowana podczas badań realizowanych w przyszłości.

\section{Zakończenie}

Analiza wyników przeprowadzonych badań wykazała, iż marketing społecznościowy odgrywa obecnie decydującą rolę w zarządzaniu relacjami z widzami seriali telewizyjnych. Ten rodzaj marketingu internetowego jest wykorzystywany przy tworzeniu strategii w social mediach i przyczynia się do kreowania oraz zacieśniania więzi odbiorców z produkcją nawet przed emisją pierwszych odcinków w telewizji. Jego skuteczność sprawiła, że tworzenie profili w mediach społecznościowych stało się częścią towarzyszącą każdemu formatowi telewizji TVN. Publikowanie na Instagramie materiałów, które ujawniają szczegóły pracy aktorów na planie, uchylają rąbka tajemnicy dotyczącej dalszych losów serialowych bohaterów lub wspominają najlepsze fragmenty z odcinków, sprawia, że obserwujące profil osoby przywiązują się do serialu. Ponadto posługiwanie się przy prowadzeniu serialowego Instagrama różnymi rodzajami głosowań, quizów oraz pytań dotyczących fabuły pozwala widzom odczuwać, że ich spostrzeżenia są ważne dla produkcji oraz zachęca ich do zaangażowania. To właśnie wyżej wymienione rodzaje postów wywołują najwyższe aktywności obserwujących konto instagramowe badanej produkcji Zakochani po uszy, co stanowi odpowiedź na jedno z pytań badawczych postawionych we wstępie do powyższej pracy.

Ponadto wyniki badań wskazują na fakt, że opinie osób aktywnych na Instagramie wpływają na działania i decyzje podejmowane przez osobę odpowiedzialną za prowadzenie profili w mediach społecznościowych serialu, co rozstrzyga część kolejnego pytania badawczego, sformułowanego we wprowadzeniu. Pomimo braku bezpośredniego wpływu widzów Zakochanych po uszy na scenariusz ich negatywne odczucia (np. względem poszczególnych bohaterów) były brane pod uwagę. Podejmowane zostają próby zmiany nastawienia odbiorców (ocieplanie wizerunku nielubianych postaci, ograniczenie ich obecności w serwisach społecznościowych, bezpośrednie zwroty do widzów).

Wzrost lub spadek oglądalności serialu skutkuje analogicznymi wahaniami poziomu zaangażowania użytkowników w mediach społecznościowych. Wniosek ten 
dostarcza odpowiedzi na pytanie badawcze o współzależność między oglądalnością a aktywnością obserwatorów w social mediach. Jednakże wykorzystanie marketingu społecznościowego przyczynia się do wzrostu oglądalności za pomocą publikacji na Instagramie materiałów, które angażują emocjonalnie widzów.

Ilość udostępnianych treści ma wpływ na zasięgi, które osiągają poszczególne posty. Publikowanie ponadprzeciętnej liczby materiałów w ciągu dnia powoduje rozkładanie się zaangażowania użytkowników, przede wszystkim za sprawą algorytmu Instagrama, który filtruje posty ukazujące się na stronie głównej. Powyższe stwierdzenie zawiera odpowiedź na ostatnie pytanie badawcze, które postawione zostało we wprowadzeniu.

Celem pracy była analiza wpływu marketingu społecznościowego na zarządzanie relacjami $\mathrm{z}$ widzami serialu telewizyjnego, a zastosowanie triangulacji metod badawczych umożliwiło przeprowadzenie jej w sposób wielowymiarowy. Posłużenie się narzędziem kwestionariusza ankiety pozwoliło wysnuć wniosek, że osoby, które wzięły udział w badaniu, w większości nie były zainteresowane produkcją Zakochani po uszy. Niemal 90\% wszystkich respondentów nigdy nie zaglądało na profil serialu na Instagramie, a ponad $65 \% \mathrm{z}$ nich nie obejrzało ani jednego odcinka. Powyższe rezultaty ukazują tendencje do niewielkiego zainteresowania polskimi produkcjami, co potwierdza informacje pozyskane w trakcie wywiadu swobodnego pogłębionego, mówiące, iż obecnie odbiorcy nie chcą oglądać polskich seriali, a zamiast tego chętniej korzystają z serwisów takich jak Netflix lub HBO GO.

Jednakże przeprowadzone badania dowodzą, iż wykorzystanie konwergencji mediów i marketingu społecznościowego pozwala zacieśniać więzi z osobami, które z różnych powodów zdecydowały się rozpocząć oglądanie serialu, i w ten sposób utrzymywać go na antenie, co widać na przykładzie strategii realizowanej przez produkcję Zakochani po uszy. Tego typu współpraca mediów tradycyjnych i społecznościowych staje się zatem podstawą zarządzania relacjami z widzami i niebawem może okazać się niezbędna, aby zachęcić odbiorców do oglądania polskich seriali w telewizji.

\section{Bibliografia}

Babbie E. (2003). Badania społeczne w praktyce. Warszawa: Wydawnictwo Naukowe PWN.

Bakhshi S., Shamma D.A., Gilbert E. (2014). Faces Engage Us: Photos with Faces Attract More Likes and Comments on Instagram. Toronto: CHI, One of a CHInd, s. 965-974.

Barańska M. (2017). Rola autopromocji w zarządzaniu ofertą telewizyjną. „Zeszyty Prasoznawcze", 4(232), s. 779-804.

Bednarowska Z. (2015). Desk research - wykorzystanie potencjału danych zastanych w prowadzeniu badań marketingowych i społecznych. „Marketing i Rynek”, 7, s. 18-26.

Burrell G., Morgan G. (1979). Sociological Paradigms and Organizational Analysis. London: Heinemann. 
Charmaz K. (2013). Teoria ugruntowana. Praktyczny przewodnik po analizie jakościowej. Warszawa: Wydawnictwo Naukowe PWN.

Cichocki P., Jędrkiewicz T., Zydel R. (2012). Etnografia wirtualna [w:] D. Jemielniak (red.), Badania jakościowe. Metody i narzędzia, t. 2. Warszawa: Wydawnictwo Naukowe PWN, s. $222-240$.

Czajkowska A. (2020). Real-time marketing jako forma promocji na przykładzie marek IKEA oraz Żywiec. „Zarządzanie Mediami”, 3(8), s. 303-321.

Czarniawska B. (1980). Podejmowanie decyzji. Warszawa: Wydawnictwo Uniwersytetu Warszawskiego.

Czarnota P. (2017). Wykorzystanie portalu społecznościowego Instagram w działaniach promocyjnych przedsiębiorstw. „Zeszyty Naukowe Politechniki Częstochowskiej. Zarządzanie”, 25, s. $130-139$.

Deszczyński B., Deszczyński P. (2004). Customer Relationship Management konsekwencja globalizacji. „Zeszyty Naukowe Akademii Ekonomicznej w Poznaniu”, 44, s. 168-192.

Drab-Kurowska A. (2012). Social media marketing w marketingu XXI wieku. „Problemy Zarządzania, Finansów i Marketingu", 26, s. 175-186.

Gębicka E. (2017). Media społecznościowe w procesie promocji filmów i seriali telewizyjnych [w:] K. Doktorowicz (red.), Media społecznościowe: dialog w cyberprzestrzeni, t. 2. Katowice: Wydawnictwo Uniwersytetu Śląskiego, s. 13-45.

Griffin R.W. (2002). Podstawy zarządzania organizacjami. Warszawa: Wydawnictwo Naukowe PWN.

Gudkova S. (2012). Wywiad w badaniach jakościowych [w:] D. Jemielniak (red.), Badania jakościowe. Metody i narzędzia, t. 2. Warszawa: Wydawnictwo Naukowe PWN, s. 111-129.

Hu Y., Manikonda L., Kambhampati S. (2014). What We Instagram: A First Analysis of Instagram Photo Content and User Types [w:] E. Adar, P. Resnick (eds.), The Eighth International AAAI Conference on Weblogs and Social Media. Palo Alto: The AAAI Press, s. 595-598.

Jenkins H. (2001). Convergence? I Diverge, http://hrenatoh.net/curso/nadigi/converge.pdf (dostęp: 22.03.2020).

Jenkins H. (2007). Kultura konwergencji. Zderzenie starych i nowych mediów. Warszawa: Wydawnictwa Akademickie i Profesjonalne.

Jupowicz-Ginalska A. (2010). Marketing medialny. Warszawa: Difin.

Jupowicz-Ginalska A. (2013). Efektywna promocja własna jako źródło wizerunkowego sukcesu organizacji medialnej - na przykładzie TVN S.A. „Zeszyty Naukowe Uniwersytetu Przyrodniczo-Humanistycznego w Siedlcach. Seria: Administracja i Zarządzanie”, 25(98), s. 383-402.

Kępczyński S. (2017). Media społecznościowe w marketingu. „Przegląd Współczesnych Problemów Zarządzania”, 4, s. 67-75.

Kostera M. (2003). Antropologia organizacji. Metodologia badań naukowych. Warszawa: Wydawnictwo Naukowe PWN.

Kostera M., Kownacki S., Szumski A. (2006). Zachowania organizacyjne: motywacja, przywództwo, kultura organizacyjna [w:] A.K. Koźmiński, W. Piotrowski (red.), Zarządzanie. Teoria i praktyka. Warszawa: Wydawnictwo Naukowe PWN, s. 311-396.

Kostera M., Krzyworzeka P. (2012). Etnografia [w:] D. Jemielniak (red.), Badania jakościowe. Podejścia i teorie, t. 1. Warszawa: Wydawnictwo Naukowe PWN, s. 167-188.

Koźmiński A.K. (2006). Organizacja [w:] A.K. Koźmiński, W. Piotrowski (red.), Zarządzanie. Teoria i praktyka. Warszawa: Wydawnictwo Naukowe PWN, s. 13-44. 
Modzelewska-Stalmach A. (2018). Autopromocja i budowanie marki osobistej na portalu Instagram na tle kultury narcyzmu. Analiza zjawiska na podstawie badania dziesięciu najpopularniejszych profili w serwisie. „Zarządzanie Mediami”, 1(6), s. 25-40.

Nierenberg B. (2011). Zarządzanie mediami. Ujęcie systemowe. Kraków: Wydawnictwo Uniwersytetu Jagiellońskiego.

Nierenberg B. (2015). Badanie reklamy [w:] B. Nierenberg (red.), Zarządzanie reklama. Kraków: Wydawnictwo Uniwersytetu Jagiellońskiego, s. 39-57.

O nas (2020), https://www.tvn.pl/o-nas (dostęp: 4.03.2020).

Obłój K., Trybuchowski M. (2006). Zarządzanie strategiczne [w:] A.K. Koźmiński, W. Piotrowski (red.), Zarządzanie. Teoria i praktyka. Warszawa: Wydawnictwo Naukowe PWN, s. $123-168$.

Pallus P. (2013). TVN stawia na promocję $w$ internecie. Rezygnuje $z$ billboardów, https://www. wirtualnemedia.pl/artykul/tvn-stawia-na-promocje-w-internecie-rezygnuje-z-billboardow (dostęp: 16.05.2020).

Programy informacyjne (2020), https://kariera.tvn.pl/obszary/ (dostęp: 4.03.2020).

Ramus M.J., Szczepankowski P. (2006). Podejmowanie decyzji w organizacji [w:] A.K. Koźmiński, W. Piotrowski (red.), Zarządzanie. Teoria i praktyka. Warszawa: Wydawnictwo Naukowe PWN, s. 85-122.

Szews P. (2014). Facebook, Twitter i YouTube w mediach tradycyjnych. Jak prasa, radio i telewizja wykorzystuja serwisy społecznościowe? „Media i Społeczeństwo”, 4, s. 56-73.

Świerczyńska-Głownia W. (2019). Multiplatformowa promocja treści. Prasa, radio i telewizja na sfragmentaryzowanym rynku mediów. „Zeszyty Prasoznawcze”, 1(237), s. 44-63.

Zespót zarządzający TVN Discovery Polska (2020), https://www.tvn.pl/zarzad (dostęp: 4.03.2020). 